\title{
AREA RATE REGULATION OF THE NATURAL GAS INDUSTRY
}

\author{
James E. Meeks* \\ and \\ RONALD J. LANDECK** \\ INTRODUCTION
}

Regulation of natural gas prices at the production level has traditionally posed a vexing problem for regulatory authorities. Frequently condemned as irreconcilable with the realities of the industry, conventional modes of regulatory pricing burdened the ratemaking process beyond the limits of feasible administrative control. In 1965 the Federal Power Commission responded to this situation by adopting a new regulatory scheme whereby prices were established on an area-rather than an individual producer-basis. ${ }^{1}$ Subsequently approved by the Supreme Court, ${ }^{2}$ the area approach could potentially alleviate the difficulties which plagued former pricing systems. Before considering the theoretical justification, utility, and potential scope of the area approach, it will be instructive to examine briefly the structure of the natural gas industry and the prior attempts at its regulation.

\section{ECONOMIC OVERVIEW OF THE Natural Gas INDUSTRY}

During the period of rapidly expanding demand for fuel since World War 1I, natural gas has become an increasingly important component of the nation's fuel supply. In 1945, for example, natural gas provided 13.7 percent of the total energy supply in the United

* Associate Professor of Law, University of Iowa College of Law. A.B. 1960, Oberlin College; LL.B. 1963, Columbia University.

** Member, IIlinois Bar. A.B. 1966, Princeton University; J.D. 1969, Northwestern University.

1. Area Rate Proceeding 61-1 (Permian Basin), 34 F.P.C. 159 (1965). Since this initial pronouncement the Commission has decided Area Rate Proceeding AR61-2 (Southern Louisiana), FPC Op. No. 546 (Sept. 25, 1968), aff d sub nom. Austral Oil Co. v. F.P.C.

F.2d — (5th Cir. 1970); Pipeline Production Area Rate Proceeding R P66-24 (Phase 1), FPC Op. No. 568 (Oct. 7, 1969). Decisions by Hearing Examiners have been issued in Area Rate Proceeding AR64-1 (Hugoton-Anadarko), Sept. 16, 1968; Area Rate Proceeding AR64-2 (Texas GuIf Coast A rea), Sept. 16, 1968; and Area Rate Proceding AR67-1 (Other Southwest), Sept. 22, 1969.

2. Permian Basin Area Rate Cases, 390 U.S. 747 (1968). 
States while coal accounted for 46.8 percent. $^{3}$ In 1967 , gas supplied 36 percent of the energy industry's total output compared to 26 percent for coal. Although approximately 66 percent of the natural gas sold in 1967 was consumed by industrial or commercial customers, ${ }^{\circ}$ natural gas lends itself to a variety of residential uses as well.6 In the residential and commercial markets, natural gas competes with electricity, coal, and oil. The primary competitors of natural gas in the industrial market are coal, oil, and atomic energy. Interfuel competition is affected considerably by the great costs usually incurred in switching to an alternative fuel source once the consumer has adapted to gas.?

The industry consists of three basic functional levels: production and gathering in the field; transportation, primarily through pipelines, to the area in which the gas will be marketed; and distribution to the ultimate consumer. The production of natural gas involves exploration, discovery, and extraction. Related to production is the gathering and processing function which occurs after the gas is brought to the surface. Being of variable quality, the gas is sorted according to its quality level and subjected to increased pressure, and, if necessary, refined before being transported to the carrier pipeline. ${ }^{8}$ The pipelines then transport the gas from the production fields to local distributors throughout the nation. Retail distribution to industrial, commercial, and residential consumers, the final phase in the process, is generally accomplished by a firm having a monopoly over this function within its locale.

3. 2 U.S. BuREaU of Mines, Minerals YearbooK-1960 at 4 (1961) thercinafterc cited as YEARBOOK].

4. 2 YEARBOOK-1967 at 4.

5. Id. at 755-56, 768-69; Chase Manhattan Bank, Outlook for Energy in tile United STATES 44 (1968). The industrial statistic includes gas used to generate electricity which, of course, competes with gas in the consumer market.

6. See generally A. Leeston, J. Crichton \& J. Jacobs, The Dynamic Natural Gas INDUSTRY 184-225 (1963) [hereinafter cited as LeESTON, CRICHTON \& JACOBS].

7. The potential customer can exercise a grcat deal of choice in selecting a particular fucl, but once that choice is made he is practieally locked in. See P. Garfield \& W. Lovejoy, Public Utility Economics 324 (1964) [hereinafter cited as GarfiELd \& Lovejoy]. The industrial customer is much less affected by the conversion costs than is the residential or commercial user, since the industrial user can now purchase multi-fucl boilers which allow switching from one fuel to another. LeESTON, CRICHTON \& JACOBS 213-16.

8. The major deposits of natural gas in this country are located in the states of Texas, Louisiana, Oklahoma, New Mexico, and Kansas. The reserves of quality gas in the Appalachian area have been so depleted that the region is less important today. See FPC, SALES BY Producers of Natural Gas to INTerstate Pipeline Companies- 1966 VIII-X111 (1967). 
Some integration of these three functional levels within the natural gas industry has been evidenced. Integration has been typically accomplished by the establishment of holding companies operating each distinct phase through separate subsidiaries. ${ }^{9}$ Frequently a joint venture was developed to control a particular operation. ${ }^{10}$ Nevertheless, many non-integrated, independent firms exist at all three levels.."

Rate regulation has been utilized primarily in situations where oligopoly or monopoly conditions exist or where the regulated industry competes with another regulated industry in need of protection from competition from the former. ${ }^{12}$ The protection provided by rate regulation is designed to supplement or substitute for the pressures against unreasonable prices afforded by competition and the antitrust laws. Regulation of the natural gas industry to assure adequate exploration and production to meet public needs and to control the cost to the ultimate consumer has long been considered necessary. ${ }^{13}$ The essential problems that have arisen conccrn the nature of regulation, the locus of administrative control, and determination of the facets of the industry requiring regulation. Certain aspects of the industry, particularly the retail distribution level, clearly fall within the definition of a classic monopoly. ${ }^{14}$ It is

9. See, e.g., GARFIELD \& LovejoY 434-46; Huitt, National Regulation of the Natural Gas Industry, in Public Administration and POLicy Formulation 57 (E. Redford ed. 1956) [hereinafter cited as Huitt]. See generally LeESTON, CRICHTON \& JACOBS 128-70.

10. In addition to the material cited in note 9 supra, see GARFIELD \& Lovejoy 320. For a recent example of an attempt to create joint ventures between two pipelines to construct a third, see Northern Natural Gas Co. v. FPC, 399 F.2d 953, 961-62 (D.C. Cir. 1968). See also Pacific Northwest Pipeline Corp., 22 F.P.C. 1091, 1094, $1110-11$ (1959) (joint agreements to share gathering facilities and coordinate other operating activities).

11. Garfield \& Lovejoy 320; W. Jones, Cases and Materials on Regulated INDUSTRIES 17 (1967). See generally LeESTON, CRICHTON \& JACOBS 128-70.

12. See generally J. Bonbright, Principles of Public Utility Rates 3-25 (1961) [hereinafter cited as BoNBRIGHT]; GARFIELD \& LOVEJOY 15-27, 78-83. Non-monopolistic situations where price control has been imposed to protect against market irregularities include most of the transportation industry, most agricultural price-regulated products, grain elevators, and wartime price and rent controls. Many leading cases establishing various aspects of government power to regulate prices have involved non-monopolistic situations. See, e.g., Parker v. Brown, 317 U.S. 341 (1943) (regulation of raisin prices); Nebbia v. New York, 291 U.S. 502 (1934) (control of milk prices); Brass v. North Dakota ex rel. Stoeser, 153 U.S. 391 (1894) (grain elevator rates where competition existed).

13. See generally GARFIELD \& LOVEJOY 1-15, 27-35, 301; W. JoNES, supra note 11, at 64-68; LeEston, Crichton \& JacoBs 260-81; Huitt 55-63.

14. For concise definitions of the classic public utility monopoly, see BonBright 10-13; GARFIELD \& LOVEOY $15-16$. 
economically wasteful in most instances to provide two or more gas mains to serve a single customer or area. At the transportation level, the same conclusion usually applies. Construction of pipelines, the most efficient method of bulk delivery, requires large capital expenditures, particularly since the fields are generally located at great distances from the prime Eastern and Northern industrial markets. Occasionally when the market demand is large enough to support more than one pipeline, some competition is feasible. Even then, however, the required high investment may necessitate regulation to assure the most efficient use of the facility. At best the competition is of an oligopolistic nature, indicating the need for public control..$^{15}$

Economically dissimilar from the transportation and distribution phases of the iridustry, the production and gathering function appears to be, with qualification, economically consistent with the existence of a competitive market. It is characterized by the presence of many firms, ease of entry, and a high degree of speculative investment interest. ${ }^{16}$ However, certain unique characteristics of the industry qualify the parallels between the production of natural gas and a competitive industry. First, since.a considerable amount of gas is produced in conjunction with oil drilling, supply of that "associated gas" is affected by factors having no relation to the demand for natural gas. ${ }^{17}$ Second, risks inherent in the discovery procedure, including elements of luck not usually present in the normal competitive market place, make prediction of costs hazardous until the recovery is completed. Ordinarily a firm can predict with reasonable accuracy the number of products of a certain quality which will result from investment of a given sum. An extractive industry, particularly the natural gas industry, does not enjoy such predictability. Whether any gas will be discovered from a given

15. See FTC Report on Utility Corporations, S. Doc. No. 92, 70th Cong., ist Scss., pt. 84-1, 615-16 (1935).

16. See generally P. MacAvoy, Price Formation in Natural Gas Fields 1-92 (1962) [hereinafter cited as MacAvoy]; E. Neuner, The Natural Gas Industru 1-112 (1960) [hereinafter cited as NEUNER].

17. See, e.g., GARFELD \& Lovejoy 319; Kahn, Economic Issues in Regulating the Field Price of Natural Gas, 50 AN4: ECON. Rev. 506, 507 (May 1960). The importance of the interrelationship betwcen oil and gas may be lessened by the recent development of directional drilling which allows discovery and production of only non-associated gas. See Area Rate Proceeding 61-1 (Permian Basin), 34 F.P.C. 306, 325-33 (1964) (Hearing Examiner's initial decision in the Permian case). 
expenditure and the quantity and quality of the gas produced if a discovery is made are matters of speculation. ${ }^{18}$ Finally, conservation measures under state law significantly affect natural gas production with the greatest effect on the production of associated gas. ${ }^{19}$ Thus, all of these factors at the production and gathering level provide special problems for regulation that are not clearly soluble by reference to. either a competitive market or classic monopoly regulatory policy. Any solution must be based upon an analysis of the nature and degree of competition in the industry at the production level. The possession of any monopolistic or oligopolistic power by natural gas producers may be discovered in one of two ways: structural analysis involving the number and relative size of the firms in the market or a conduct analysis which examines the pricing pattern and other conduct of the producers to determine whether these factors comport reasonably with probable conduct in a competitive market. Since abnormal conduct can occur as a result of short-range factors which will be corrected by the market over time, conduct analysis frequently fails to yield any firm conclusion. Also, monopolistic and competitive conduct often appear the same. ${ }^{20}$

The usual structural indicia of monopoly are the existence of one or a very few firms in the market and high entry barriers which protect the monopolist from potential competition within a significant price range. Neither of these factors relating primarily to

18. See, e.g., Phillips Petroleum Co., 24 F.P.C. 537, $542-45$ (1960); GARfield \& LovejoY $321-22,334$. The "luck" element does not loom as important in financial terms for the large firms because the large number of drillings permits the firm to predict the risk factor more accurately and to insure against that risk as a normal expense. Predictability has been improved for all firms through recent advances in exploration teehnology. GARFIELD \& Lovejoy 318-21. See also Permian Basin Area Rate Cases, 34 F.P.C. 159, 185-86 (1965) (opinion of the Commission); 34 F.P.C. 306, 323-29 (1964) (Hearing Examiner's opinion). However, large companies may have received the most benefit. 34 F.P.C. at 186. See GARFIELD \& Lovejoy 32031.

19. See, e.g., H. Willtams \& C. Meyers, Otl \& Gas law, Manual of Terms 321-23 (1964); Williams, Conservation of Oil and Gas, 65 HARv. L. Rev. 1155 (1952); Comment, Proration in Texas: Conservation or Confiscation, 11 Sw. L.J. 186 (1957). Related to prorating is the developing law of pooling and unitization. For a through discussion of voluntary and compulsory pooling and unitization measures, see 6 WiLliam \& MEYERS, supra $\$ \S 901-02,905$, 910,912-13.

20. For example, while relative uniformity in pricing conduct among the firms in the market is one of the indicia of monopolistic power, fully competitive market prices also tend to be uniform. The monopolistic firm's priee does not necessarily relate to cost, while the competitive market price will. 
natural or technological economies of scale ${ }^{21}$ seems to exist to any significant degree in the natural gas production industry.

Although no reliable statistics on the exact number of independent producers in the country are readily available, the figure certainly runs into the thousands..$^{22} \mathrm{ln}$ addition, a large number of potential competitors operate on the periphery of the production industry.

Sales concentration figures also indicate that concentration in natural gas production cannot readily be characterized as monopolistic or oligopolistic. The Federal Power Commission's statistics on sales by independent producers to interstate pipelines show the following concentration in sales by volume and revenue. ${ }^{23}$

First Company

First 4 Companies

First 8 Companies

First 20 Companies

First 50 Companies

First 100 Companies

All 3,509 Companies

\section{Percent of Total Production}

6.9

23.9

38.6

60.2

78.4

83.6

100.0
Percent of Total

Revenues

7.4

24.0

38.5

60.6

79.8

86.9

100.0

21. See Garfield \& Lovejoy 16-19; Bonbright 11-13.

22. Annual FPC statisties which include only producers who sell in interstate commerce and whose name first appears on the contract indicate that the number has averaged approximately 3,500. Since considerable gas is sold by consortiums of many producers, the number of producers is obviously mueb larger. Moreover, this figure does not include producers that sell only in the intrastate market. Whatever the exact number, there are enough producers that the existence of monopoly or even oligopoly power is doubtful. See the annual editions of FPC, Statistics of Natural Gas Companies from 1963 through 1967.

23. Compiled from id. (1967). Again two caveats are required. First, these statistics report only interstate sales, excluding a large market in intrastate gas. Since gas destined to the intrastate market could be diverted to the interstate market, the entire sales concentration would be a more accurate statistic. Second, sales are attributed to only one firm although several firms may be producing the gas and selling it jointly. Thus it could be argued that the FPC statistics grossly overstate the concentration. Nevertheless, since it is unlikely that there is competition between the firms engaged in any of these joint selling operations which permeate the industry, it does not seem unfair to lump the firms into dominant groups.

The concentration shown by these statistics is somewhat higher than that shown by a much more elaborate study based upon 1953 sales statisties. Although the age of that study affeets its relevance, it showed concentration ratios on volume as follows:
4 largest producers $17 \%$
8 largest producers $28 \%$
20 largest producers $46 \%$
50 largest producers $66 \%$
100 largest producers $78 \%$
NEUNER 22. 
At most these statistics indicate a moderate degree of concentration that may be characterized as a loose oligopoly. ${ }^{24}$ The concentration should not be sufficient, on a national scale at least, to give the firms pricing power. If concentration ratios are much higher in local producing areas, and there is little or no competition between areas, a different conclusion might follow. The only data available are dated and inconclusive ${ }^{25}$ and indicate that although concentration in a local area may exceed the national level, this concentration is not alarming and may be mitigated by observable interfield competition. ${ }^{26}$ Thus, it is uncertain whether oligopolistic pricing results. ${ }^{27}$

The apparent lack of significant sales concentration does not preclude the existence of barriers to entry or other forms of market power in the producers. Since this is a "wasting asset" industry in which supply is limited by nature, control over known reserves can provide substantial market power by creating barriers to entry or expansion. The only available data indicate that while concentration in reserve ownership is somewhat higher than in sales, the level of control does not appear threatening. 28

The costs associated with exploration for new gas finds, leasing mineral rights, and the inevitable dry holes constitute substantial barriers to entry or expansion in the production of natural gas. Because exploration costs must be financed predominantly from

24. This conclusion is based on the definitions and probable behavior patterns developed in $J$. BAIN, INDUSTRIAL ORGANIZATION 25-36 (1959).

25. See Neuner 35-42, 113-205.

26. Id. at 246-5I. Only one of the area cases discusses concentration statistics for the area. See Hugoton-Anadarko Area Rate Cases, No. AR64-1, at 8 (F.P.C. Sept. 16, 1968) (Hearing Examiner's decision).

27. Neuner found no effect upon price in his study. NeUNER 256-64. See also MaCAvoy 24365.

28. Using I953 date and making several adjustments, Neuner, in his study, arrived at the following figures:

$\begin{aligned} 5 \text { largest holdings } & 27.0 \text { to } 31 . I \% \\ 10 \text { largest holdings } & 34.9 \text { to } 40.2 \% \\ 15 \text { largest holdings } & 39.5 \text { to } 45.5 \% \\ 25 \text { largest holdings } & 45.6 \text { to } 52.5 \%\end{aligned}$

NEUNER 16-18. The first percentage includes reserves held by pipelines and their affiliates in the total reserve figures. The second percentage in each column is figured without including the pipeline reserves. Unfortunately, both the dated nature of the data and the enormous additions to reserves since 1953 decrease the reliability of the figures above. Estimated reserves in 1953 were 211.5 trillion cubic feet (TcI). AM. GAS. J., March I954, at 19. The cumulative discovered gas in 1968 was 628.2 Tcf with $284.5 \mathrm{Tcf}$ of that amount remaining as reserves. FPC BUREAU OF Natural Gas, Staff Report on National Gas Supply and Demand 20 (1969). 
internal sources, ${ }^{29}$ the larger, established firm has a distinct advantage. In addition, larger firms are able to buy up the mineral rights leases at relatively low prices and control the exploration of areas most likely to be productive well in advance of any actual development in the locale.

Nevertheless, entry by a large number of small and new producers in recent years suggests that these barriers have had little effect. ${ }^{30}$ Their entry may be partially explained by two factors. First, the large firms frequently support "wildcatting" by the small firms; this enables the large firms to spread the cost of more speculative exploration and later move in to help develop any significant find. ${ }^{31}$ Second, since gas is almost always discovered in conjunction with oil and other hydrocarbons, ${ }^{32}$ about 75 percent of the costs of exploring for and producing oil and gas are joint costs. Thus, the risk of exploration may often be spread between oil and gas production, encouraging exploration by both small and large firms.

In summary, the producer level appears to be neither monopolistic nor oligopolistic in structure. Indeed, a strong argument can be made that the market is monopsonistic with the pipeline purchasers occupying a significantly superior bargaining position. ${ }^{33}$ In 1957, four interstate pipelines purchased 43.9 percent of the national sales volume of natural gas and an even higher percentage from the major producing areas of the South and Southwest. ${ }^{34}$ Moreover, the buying concentration in any particular field is probably even more pronounced. Entry is highly restricted at the buyer level; to have several pipelines serving each field would be economically wasteful..$^{35}$

Despite this evidence that monopoly structure does not exist at the producer level and that monopsonistic power may exist among buyers, the suspicion persists that production level prices are not

29. "The risks of exploration are such that financial institutions will not lend money for this purpose on the security of the assets that may be discovered by a proposed exploratory effort." GARFIELD \& LOVEJOY 334.

30. See GARField \& Lovejoy 320-21.

31. Id. at 321.

32. The natural result is that the major oil companies are also the largest gas producing companies. Id. at 294-95, 317-21.

33. Id. at 323; MACA VoY 243-46. See generally NeUNER 125-34 (one pipeline constituted the only major interstate buyer in the Permian area until at least 1952).

34. GARFIELD \& LOVEJOY 323.

35. For a description of various agreements designed to avoid waste and duplication by sharing gathering facilities in the field, see Pacific Northwest Pipeline Corp., 22 F.P.C. 1091, $1111(1959)$. 
entirely competitively set. The Federal Power Commission has so found ${ }^{36}$ The suspicion that at least some producers are making excess profits is reinforced by the phenomenal increase in gas field price since $1945^{37}$ and the relatively recent attempts to set prices in the new fields at much higher rates than previously existed. ${ }^{38}$ While these instances illustrate that the producers were able to negotiate a higher price than the Commission staff thought reasonable on a cost basis, they do not conclusively establish the unreasonableness of such negotiated prices but merely demonstrate that the pipeline purchasers did not have, or did not exercise, complete power in the pricing mechanism. Therefore, an inquiry must be made into rigidities in the market that might inhibit competitive pricing.

One such rigidity might be a lack of self-interest on the part of the buyer, the pipeline, to force the price to its lowest possible level since the pipeline knows that it can recover full cost of the gas as an expense item in its rates to its own customers. An important factor only after World War I1, the pipelines fought for a relatively limited supply of. gas to meet the booming demand for fuels. Since the price of other fuels was also increasing rapidly, natural gas producers could demand extraordinary price increases, despite the monopsonistic or oligopsonistic nature of the market..$^{39}$ The only limit on producer prices was the maximum price which could be exacted without losing the consumer market to other fuels, and that maximum price may or may not have had any relation to cost factors at the production level. Absent monopoly power, prices should level off or decline as high profits encourage the entry of additional suppliers to meet the increased demand. If such circumstances persisted over a long period, however, regulation of producer prices might well be justified despite

36. See Permian Basin Area Rate Proceeding, 34 F.P.C. 159, $181-83$ (1965). In fact, however, it is an open question whether the Commission would have so held but for the Supreme Court's Phillips decision requiring regulation. See notes 69-71 infra and accompanying text.

37. See, e.g., Kahn, supra note 17; Kitch, The Permian Basin Area Rate Cases and the Regulatory Determination of Price, 116 U. PA. L. REv. 191, 196 (1967); Kitch, Regulation of Field Market for Natural Gas by the Federal Power Commission, 11 J. LAw \& Econ. 243, 26264 (1968) [hcreinafter cited as Kitch]. All of the authorities, except Professor Kahn and the Permian case itself, argue that the price increase was not traceable to monopolistic pricing.

38. See Atlantic Ref. Co. v. Public Serv. Comm'n, 360 U.S. 378, 388 (1959) (CATCO); Johnson, Producer Rate Regulation in Natural Gas Certification Proceedings: CATCO in Context, 62 Colum. L. ReV. 771 (1962).

39. See Permian Basin Area Rate Proceedings, 34 F.P.C. 159, 182-83 (1965); Garfield \& LOVEJOY 319-20, 325; NeUNER 119-23; Kitch 257-65. 
the lack of permanent monopoly power..$^{40}$ Whether a spiralling producers' price exists today is difficult to determine since a negotiated field price is no longer available for use as a reference point."1 One dubious indication that field prices would have continued to rise but for FPC-imposed ceilings is the producers' consistent pressure for a higher ceiling. ${ }^{42}$ Moreover, contract prices at a rate below the ceiling have continued to rise slightly..$^{43}$

On the other hand, the average price of gas at the wellhead seems to have leveled off since 1960.44 Moreover, the pipelines have apparently caught up with the abnormal increase in demand which followed World War II. Finally, gas prices may have reached a maximum relative to competitive fuels in many market areas. ${ }^{45}$ Thus for a pipeline to continue to grow at a desirable rate, it must seek to cut its costs by bargaining for the cheapest possible price in the field.

However, several additional factors also suggest that pipelines

40. Public regulation may be necessary to prevent an economic rent or profit in excess of the amount required to call forth the necessary supply during conditions of a relatively fixed supply of a natural resource and an incrcasing demand. These excess profits are due to searcity and may occur in a competitive market with low factor mobility. See GARFIELD \& Lovejoy 323-24; NEUNER xix. Kahn, supra note 17, at 506. Both MacAvoy and Kitch conclude that price control excluding recovery of such profits may have an adverse effect upon exploration for new reserves and allocation of the resourcc in general. MACAvoY 255-62; Kitch 276-80. These fears may have been justified. The FPC staff has issued a report detailing a critical shortage in reserves and emphasizing the need to induce substantial new exploration to avoid a gas shortage crisis in the very near future. FPC Bureau of Natural Gas, Staff Report on National Gas Supply AND Demand (1969). See also Fortune, Nov. 1969, at 120. The Commission has rcsponded in some measure. See notes 206-17 infra and accompanying text.

41. With the advent of the area cases in 1960 , the Commission established ceiling priccs based upon the then existing field prices which were to be used until the area rate cases were concluded. Thus the most rccent reliable prices resulting from negotiations are almost ten years old. See FPC Statement of General Policy, No.614, 18 C.F.R. § 2.56 (1970); 24 F.P.C. 818 (1960). Sce also Phillips Petrolcum Co., 24 F.P.C. 537 (1960).

42. Recent statements by some distributors, traditionally infuenced by consumer pressure to seck lower prices, indicate that they too favor price inereases to encourage exploration for additional supply. See ForTUNe, Nov. 1969, at 120. Producers and pipelines have also tried various devices to circumvent the price restrictions. For a description of these attempts and the Commission's response, see Kitch 269-76.

43. See, e.g., FPC 1968 ANN. REP. 55-56.

44. See GARFIELD \& Lovejoy 325; Kitch 265.

45. Seee, e.g., Fuels Research Council, 1ne. v. FPC, 374 F.2d 842 (7th Cir. 1967); Natural Gas Pipeline Co. of America, 28 F.P.C. 731 (1962). See GARFIELD \& Lovejoy 325; Kitch 265-67. Cf. Chase Manhattan Bank, supra note 5, at 15-46; FPC Federal Power Survey 12 (1964). Gas companies have occasionally sought discriminatory prieing in order to competc with other fuels. Recent evidence indicates that the cumulative residential and industrial demand for all fuels continues unabated. Ehrich, A Shortage of Energy Threatens Industries and Homes Across U.S., The Wall St. Journal, June 2, 1970, at 1, col.6. 
may have little or no incentive to bargain for lower prices. First, distance and use factors significantly affect the level of competition between fuels in any particular market. Second, pipelines owning reserves may have an incentive to enhance the value of their reserves by permitting higher prices for the independent producer ${ }^{46}$ Finally, even assuming that the pipelines have an incentive to bargain for lower prices, the competition with other fuels only places an upper limit upon the field price. That price has no relationship to gas production costs since cost factors in each competing fuel industry will be quite different.

Another possible inhibition on competitive pricing is the cooperative action among producers. Perhaps the most important instance of cooperative effort, designed to spread the risk and to amass the capital necessary for exploration and development, is the joint leasing and early development of the fields with each producer taking a pro rata share of expenses and returns. ${ }^{47}$ Nevertheless, these cooperative arrangements should not make the industry oligopolistic unless they involve the interaction of most of the producers in each field and are dominated by the larger firms. Although no proof was found, it seems highly probable that this latter situation in fact exists.

Another unique feature of the industry which may substantially detract from competitive pricing is the widespread use of long-term requirements contracts with built-in price adjustment clauses. Such contracts preclude most possible competition between producers except when a pipeline first moves into a field or undertakes a large expansion project. Even if the pipelines attempt to play one producer

46. The Commission cited this possibility in the Permian decision. 34 F.P.C. 159, 182 (1965). However, the Commission has subsequently acted to prevent the pipelines from recovering this enhanced value in their own rates. See Pipeline Production Area Rate Proceeding, R P66-24, FPC Op. No. 568, at 4 (Oct. 7, 1969) and cases cited there. See also GARFIELD \& Lovejoy 311 12. The Commission has now applied the area rate approach to new gas supplies mooting the question under discussion as to that component. Pipeline Production Area Rate Proceeding, supra. However, the pipclines may be free to sell their reserves to an independent producer to recover the enhanced value indirectly. See Panhandle Eastern Pipe Line Co. v. FPC, 324 U.S. 635 (1945). But cf. Continental Oil Co., No. G2737, Op. No. 542, UTIL. L. REP. I 10,957 (FPC, June 27,1968 ) (where pipelines sold production properties to independents and subsequently purchased gas taken from the property, the pipeline was only entitled to a rate that reflected original cost of the production property, rather than the price paid to the independent for the gas).

47. These statcments are based primarily upon information supplied by lawyers knowledgeable in the area. $C f$. GARFIELD \& LoveJOY 321-22. It seems odd that none of the economic studies of the industry perused treated the importance of this upon the competitive structure and conduct of the industry. 
against another to get the lowest price during these periods, the pipelines frequently need such a great volume of gas that real competition between producers is nonexistent. In a market where buyers are seeking a large product unit involving only a few sales possibilities a year, the sellers are likely to act oligopolistically to assure that each gets part of the market. Moreover, if no one seller can satisfy the total demand for the product unit, cooperation among the seller group to meet the demand is likely. Significant price competition under these circumstances is unlikely. Typically covering a period of twelve to twenty years, these large quantity contracts aim to assure a supply to both the pipeline firms and their ultimate consumers. ${ }^{48}$ To protect itself from rising costs and to assure that it will get back any enhancement in the value of the gas over the contract period, ${ }^{49}$ the producer typically seeks an escalation clause..$^{50}$ Under the market conditions outlined above, the pipelines should have been less willing to accept such provisions. However, at least until the FPC prohibited non-cost-related provisions in future contracts, ${ }^{51}$ the pipelines continued to accept such clauses.

48. The FPC has consistently required a showing of adequate supply before it will certify a pipcline project. Kansas Pipe Line \& Gas Co., 2 F.P.C. 29, 40 (1939). Initially demanding a showing of adequate supply for twenty years, the Commission has more recently adopted a method under which a twelve year contract is permissible. See Garfield \& Lovejoy 313.14. Perhaps even a lesser showing may suffice. E.g.. Texas-lllinois Natural Gas Pipeline Co., 22 F.P.C. 979, 980-81 (1959). See generally 1968 FPC ANN. REP. 48:

The Commission is continuing its policy of flexible gas reserves and deliverability requirements for established pipelines with active gas procurement programs and for pipelines extending into production areas where active exploration is continuing. This reflects the FPC's continuing reliance on demonstrated management performance and judgment in maintaining gas supplies. Id.

This relaxed standard for certification has probably had little actual impact on the normal contract period since the pipelines will normally assure themselves of a long-term supply.

49. Note that while the producer's first goal is, of course, justifiable on cost grounds, the second goal is not cost related, but value related.

50. Under a most favored nation clause, the most common escalation provision, the contract price automatically increases if a new contract in the arca is negotiated at a higher price. Another example is a price redetermination clause providing for periodic renegotiation of price throughout the term of the contract. See Neuner 80-111. Thus the producer may exercise substantial price control whenever uncommitted reserves exist in the area covered by the contract. The producer may bargain on the price for uncommitted reserves to increase the ficld price, thereby enhancing the price of the previously committed gas, regardless of his costs.

51. Non-acceptability of Contracts Between Producers and Interstate Natural-Gas Companies Containing Certain Types of Automatic Escalation and Favored Nation Clauses, 25 F.P.C. 379 (1961), modified, 27 F.P.C. 339 (1962), 18 C.F.R. $\S 154.93$ (1970). This prohibition was approved in FPC v. Texaco, Inc., 377 U.S. 33 (1964). See also Permian Basin Area Rate Cases, 34 F.P.C. 159, 236-37 (1965), aff d, 390 U.S. 747, $781-84$ (1968). 
A nother price phenomenon which may limit the effect of anticompetitive practices is competition between fields. Substantial evidence suggests that this exists although the producer-sellers apparently 'still retain substantial price control. As a new field is opened, a prevailing price is established for the initial purchases. The price then begins to rise until it reaches a point where the pipeline can get gas in another new field at a competitive price including the cost of construction of the necessary new pipeline. The price in the older field then stabilizes at the price level prevailing initially in the new field. However, this equilibrium is short-lived. The process soon repeats itself with the price in both the new and the old field rising again until it reaches a level equivalent to that in yet another new field. Repetition of this process results in a continual price rise in all fields..$^{52}$

Another factor clearly affecting the market and price for gas is the close production relationship to oil. For example, a firm engaged in both oil and gas production may attempt to allocate the greater share of the joint production costs to whichever product faces the least competitive pressure. Since oil industry competition has been relatively intense in recent years, a disproportionate share of the joint production costs has likely been assigned to gas. ${ }^{53}$ Further, since gas supply is significantly affected by exploration for and discovery of oil, no completely reliable relationship exists between supply and demand for gas. If there is no advantageous market for oil, a firm may be less inclined to develop new wells merely to seek gas. The potential influence of demand for oil on the gas supply is especially great in fields like the Permian Area where predominantly associated gas is produced.

Conclusions from this analysis of the economics of the gas market are hazardous at best. However, it seems reasonably clear that the industry is not monopolistic. While this does not necessarily mean that a free market would result in competitively set prices, it does suggest that the market for gas at the production level is oligopolistic at most and that perhaps no regulation of producer prices is necessary.$^{54}$ However, Congress has required such regulation. The

52. See Neuner 65-70. However, Neuner did not conclude that this was the result of seller pricing power.

53. See GARFIELD \& Lovejoy 324, 337. See also Kahn, supra note 17, at 510-17; Fortuñ, Nov. 1969, at 120, 190; FORTUNE, June 1969, at 105, 109.

54. See, e.g., MacAvoy 4-8; Neuner 280-90; Kitch at 243; Kitch, The Permian Basin Area Rate Cases and the Regulatory Determination of Price, 116 U. PA. L. REv. 191 (1967). 
method of regulation adopted by the Commission to fulfill this congressional mandate can now be tested in light of this economic framework.

\section{A BRief History of Federal Regulation}

Prior to 1938 the federal government did not directly regulate any phase of the gas industry. Incidents of indirect control were evident in the Connally "Hot Oil" Act, ${ }^{55}$ which affected production of associated gas to the extent that it regulated oil production. The Supreme Court as late as 1931 , however, viewed production of gas as a "mining operation" regulable only by the states..$^{56}$ The public utility nature of the distribution process led early to local, and then state, regulation at that level, and many of the producing states imposed regulation in the interest of conserving the resource and stabilizing the market. State regulatory efforts at both levels proved ineffective as the industry grew. Price and service increasingly depended on the practices of the interstate pipeline system over which the states had no regulatory jurisdiction. ${ }^{57}$

In 1928 the Federal Trade Commission received congressional authorization to investigate utility holding companies and suggest remedial legislation. ${ }^{58}$ The Commission's report recommended that

[a] Federal regulatory law should be enacted applicable to interstate natural gas pipelines which transport gas for ultimate sales to and use by the public, regulating contracts for purchase of gas to be transported interstate, or regulating rates for carriage or city gate rates at the end of such transportation, or all of these. Security issues, accounts, beginning and abandonment of operations, and intercorporate relations of companies owning or controlling gas-pipelines should also be regulated..$^{59}$

This recommendation resulted in the enactment of the Natural Gas Act of $1938 .{ }^{60}$ Administered by the Federal Power Commission,

\footnotetext{
55. 15 U.S.C. $\S \S 715-715 l$ (1964).

56. Champlin Refining Co. v. Corporation Comm'n, 286 U.S. 210 (1931).

57. Operation of the interstate pipelines involved interstate commerce over which, under the prevailing view of the commerce clause, only Congress could exert control. Missouri ex rel. Barrett v. Kansas Natural Gas Co., 265 U.S. 298 (1924). Sec also East Ohio Gas Co. v. Tax Comm'n, 283 U.S. 465 (1931); Public Util. Comm'n v. Attleboro Stcam \& Elec. Co., 273 U.S. 83 (1927); Pennsylvania v. West Virginia, 262 U.S. 553 (1923); United Fuel Gas Co. v. Hallanan, 257 U.S. 277 (1921); Eureka Pipe Line Co. v. Hallanan, 257 U.S. 265 (1921); Oklahoma v. Kansas Natural Gas Co., 221 U.S. 229 (1911).
}

58. S. Res. No. 83, 70th Cong., Ist Sess., 69 Cong. ReC. 3054 (1928).

59. S. Doc. No. 92,70 th Cong., 1 st Sess. pt. 84A, at 616-17 (1936).

60. 15 U.S.C. $\S \S 717-17 w(1964)$. 
the Act contains four sections which are important for this article. Section 1, establishing the jurisdictional guidelines, makes the Act applicable to natural gas companies selling in interstate commerce. ${ }^{61}$ Section 4 requires firms to file notice of rate changes and authorizes the suspension of such changes for a five month period. ${ }^{62}$ Section 5 authorizes the Commission to investigate rates and to lower those rates which are not just and reasonable. ${ }^{63}$ Section 7 requires any firm covered by the Act to secure a certificate of public convenience and necessity from the Commission before entering into the gas business or constructing any significant facility. ${ }^{64}$ If a company fails to secure a certificate or operates beyond the range of activity which the certificate allows, the company may be prohibited from operating in the natural gas industry.

In Federal Power Commission v. Natural Gas Pipeline Co. ${ }^{65}$ the Supreme Court upheld the constitutionality of the Act. The Court reasoned that the Act was a valid exercise of Congress' commerce power, at least as applied to firms transporting gas in interstate commerce. The Court concluded, moreover, that the Act's regulatory power extended to the production activity of integrated firms to the extent that their gas eventually reached the interstate market. ${ }^{66}$

Prior to 1954, production and sales by non-integrated firms were not subject to regulation under the Act even though the firms' gas entered interstate commerce immediately after the sale. ${ }^{67}$ The price charged a pipeline company by an independent producer was an expense item in the pipeline's rate-making formula. ${ }^{68}$ The Commission generally failed to question the reasonableness of this price in its regulation of the pipeline. As a result, the FPC controlled only the price and costs of production by integrated producers. The hiatus created by this dual regulatory approach prevented the Commission from adopting a consistent policy; pressure to equalize

61. Id. $\$ 717$.

62. Id. $\S 717 \mathrm{c}$.

63. $I d . \S 717 \mathrm{~d}$.

64. $I d . \S 717 \mathrm{f}$.

65. 315 U.S. 575 (1942).

66. Id. at 582-83. The Court also held that regulation under the Act met the requirements of due process. Id. at 583-85.

67. Columbia Fuel Corp., 2 F.P.C. 200,208 (1940). The Commission qualified its decision by stating that if monopoly conditions existed in the industry at some future date, the question of producer regulation would be reopened. Id.

68. See, e.g., GARFIELD \& Lovejoy 304. 
regulatory treatment of the two elements of the production industry was inevitable.

In 1954 the Supreme Court held that the Act's rate provisions also applied to independent producers to the extent that their gas entered interstate commerce. ${ }^{69}$ Noting that the stated purpose of regulation is "[p]rotection of consumers against exploitation at the hands of natural gas companies," existed either in the Act or in the legislation's purpose upon which to base different treatment of integrated and independent producers. Thus, the Commission's jurisdiction was significantly changed, requiring modifications in its regulatory scheme. ${ }^{71}$

\section{Regulation of Rates Prior to 1960}

Ratemaking in the natural gas industry has posed a most perplexing problem for the Federal Power Commission since its inception. In 1898 in Smyth v. Ames, ${ }^{72}$ the landmark decision on governmental control of rates, the Supreme Court held that a rate should yield a return upon the fair value of the property being used for the public convenience. The factors enunciated by the Court to determine fair value included:

the original cost of construction, the amount expended in permanent improvement, the amount and market value of the bonds and stocks, the present as compared with the original cost of construction, the probable earning capacity of the property under particular rates prescribed by statute, and the sum required to meet operating expenses . . . .

In practice this suggestion was translated into a requirement that the fair value of property must include consideration of: original cost plus cost of improvements, less depreciation; current market value of the

69. Phillips Petroleum Co. v. Wisconsin, 347 U.S. 672 (1954). The decision rcmains controversial. For an argument that the legislative history of the Act does not support the Court's decision and a description of the attempts at congressional reversal of the Phillips decision, see Kitch 243, 254-57.

70. 347 U.S. at 685.

71. The Phillips case involved sales following production, gathering, and processing. Decisions following Phillips have extended federal regulatory control to sales of gas at the wellhead. California v. Lo-Vaca Gathering Co., 379 U.S. 366, 369 (1965) (dictum); Continental Oil Co. v. FPC, 266 F.2d 208 (5th Cir.), cert. denied, 361 U.S. 827 (1959); Saturn Oil \& Gas Co. v. FPC, 250 F.2d 61 (10th Cir. 1957), cert. denied, 355 U.S. 956 (1958); Shell Oil Co. v. FPC, 247 F.2d 900 (5th Cir. 1957); $c f$. United States Improvement Co. v. Continental Oil Co., 381 U.S. 392 (1965).

72. 169 U.S. 466 (1898).

73. Id. at $546-47$. 
property; and current cost of reproducing the property. ${ }^{74}$ However, no formula existed to indicate the relative importance of these often conflicting factors.

This uncertainty over the propriety of a given rate structure, created by attempts to reconcile basically inconsistent theories, led to the brilliant concurring opinion of Mr. Justice Brandeis in Southwestern Bell. ${ }^{75}$ Critical of determinations of the rate base from estimates of the value of the assets employed in the public service, he advocated the use of the rate base as "a fact, not determined as a matter of opinion." avoid the wild uncertainties of Smyth by determining precisely what had been invested in the business and using that amount as the rate base. Similarly, the theory adopted the readily-determinable amount of the capital charge, both as to debt and equity, as the measure of the rate of return. Reasserted frequently in minority opinions, ${ }_{2}^{77} \mathrm{Mr}$. Justice Brandeis' prudent investment theory was finally adopted as the governing standard by the FPC. . $^{8}$

The Supreme Court upheld the use of the prudent investment theory in Federal Power Commission v. Hope Natural Gas Co. ${ }^{79}$ Hope, an integrated natural gas company, was charged with exacting unreasonable rates and discriminating in favor of industrial buyers. In affirming the FPC's order that Hope reduce its rates, the Court explicitly rejected the fair value approach and declared that "fair value' is the end product of the process of ratemaking not the starting point . . . ."80 The Court then attempted to delineate the judicial role in passing upon rate questions.

It is not theory but the impact of the rate order which counts. If the total effect of the rate order cannot be said to be unjust and unreasonable, judicial inquiry under the Act is at an end. The fact that the method employed to reach that

74. See Bonbright 163, 170; Garfield \& Lovejoy 58-60. See generally C.. Phillips, The Economics of Regulation 214-40 (1965); Hale, Conflicting Judicial Criteria of Utility Rates-The Need for Judicial Restatement, 38 CoLum. L. Rev. 959 (1938).

75. Southwestern Bell Tel. Co. v. Public Serv. Comm'n, 262 U.S. 276, 289 (1923).

76. Id. at 306.

77. See, e.g., McCart v. Indianapolis Water Co., 302 U.S. 419, 436 (1938) (dissenting opinion); St. Louis \& O'Fallon Ry. v. United States, 279 U.S. 461, 488 (1929) (dissenting opinion); McCardle v. Indianapolis Water Co., 272 U.S. 400, $421-22$ (1926) (dissenting opinion); Bluefield Water Works \& Improvement Ce. v. Public Serv. Comm'n, 262 U.S. 679 (1923) (concurring opinion).

78. Hope Natural Gas Co., 34 F.P.C. 150 (1942).

79. 320 U.S. 591 (1944).

80. Id. at 601 . 
result may contain infirmities is not then important . . . . And he who would upset the rate order under the Act carries the heavy burden of making a convincing showing that it is invalid because it is unjust and unreasonable in its consequences. ${ }^{81}$

In this instance the "end result" doctrine reflects judicial deference to administrative decision. By definition, however, the end result test is not without standards. The rate must be sufficient to protect the investor's legitimate interest in the financial integrity of the regulated company by enabling the company to operate successfully and attract capital. Furthermore, the investor should be assured that his return will be commensurate with the return on investment of other enterprises having corresponding risks. ${ }^{82}$ The Court concluded that rates meeting these requirements "certainly cannot be condemned as invalid, even though they might produce only a meager return on the so-called 'fair value' rate base."

In a vigorous dissent, Mr. Justice Jackson expressed two primary concerns. Noting first that natural gas is a wasting asset of limited supply, he contended that price regulation should place particular emphasis upon conservation through a pricing policy that would encourage the use of natural gas when its social and economic return to the public is high and discourage use where the social utility is low. Preservation of existing supply for optimal uses, he noted, should be the first concern of regulation.84 The idea that regulatory control over prices should be adapted to achieve social and economic goals, other than seeking the lowest price to the consumer consistent with a fair return to the investor, was novel in the Supreme Court. While Mr. Justice Jackson's views on the necessity of conserving gas resources may have been overstated in light of subsequent large discoveries, his utilitarian or functional approach to ratemaking is still important.

His second attack upon the majority's acceptance of the prudent investment theory centered upon his view that the production aspect of the gas industry did not fit the economic model of a public utility ${ }^{85}$ Therefore, he contended, the "fair return on investment" theory with its requisite determination of a rate base was not really effective in arriving at a proper price. Under his view the industry possessed two
81. Id. at 602 .
82. Id. at 603 .
83. Id. at 605 .
84. Id. at 634-35.
85. Id. at 628-60. 
diverse facets-production and transportation. The transportation component, he acknowledged, involved an operation "not differing substantially" from many other utility activities. In this situation, the consumer receives none of the company's physical property but only utilizes it. Moreover, the difficulty of appraising the value of the "intangible service" provided by the pipeline in a monopoly or ncar monopoly context is manifest. Since the service of such a utility relates to the company's capital investment, he concluded, a "rate base calculated on the prudent investment formula [through valuation of the assets involved] would seem a reasonably satisfactory measure for fixing a return from [the transportation] ... branch of the business ...." ."86

He argued, however, that the prudent investment theory was not intended nor well suited for application to the production phase of the natural gas industry because of the inherent uncertainty of that process. ${ }^{87}$ The cost of discovering gas and reducing it to possession fluctuates widely depending on the vicissitudes of discovery, largely uncontrollable by even the most efficient methods. ${ }^{88}$ This makes a rate base determination hazardous at best, because of the difficulty of assigning value to such intangibles as the leaseholds and freeholds where attempted discovery might or might not be successful. Using a prudent investment theory, he contended, ignores these varying costs of discovery and leads to widely divergent returns unrelated to the value of the gas to the consumer. In terms of consumer interest, $\mathrm{Mr}$. Justice Jackson felt that producers should not receive different prices for the same product simply because the total production costs varied, a result of varying amounts of capital investment. "The service one renders to society in the gas business is measured by what he gets out of the ground, not by what he puts into it . . . ." Consequently, Mr. Justice Jackson preferred use of the market price of the gas in the field, not the rate base, as the measure of the portion of the rate not

86. Id. at 647 .

87. In short, he contended,

[t] he prudent investment theory has relative merits in fixing rates for a utility which creates its service merely by its investment. The amount and quality of service rendered by the usual utility will . . . be measured by the amount of eapital it puts into the enterprise. But it has no rational application where there is no such relationship between investment and capacity to serve. There is no such relationship between investment and the amount of gas produced. Id. at 649 .

88. Id. See also OIL \& GAS J., Apr. 24, I96I, at 92.

89. 320 U.S. at 649. 
associated with the transportation function. "Gas itself is tangible, possessible, and does have a market and a price in the field. The value of the rate base is more elusive than that of gas." ${ }_{00}$ This approach assumes a more or less competitive market for gas in the field to protect the consumers' interest.

Consistent with the Court's statement in Hope that it would only scrutinize the end result of the method of rate control the Commission used, the following year the Court implied that it might affirm use of the field price approach if it were adopted by the Commission. In Colorado Interstate Gas Co. v. Federal Power Commission," the Commission had included the company's producing properties in its rate base at their net original cost. The company argued that the correct procedure would adopt instead the "fair field price of the gas as a commodity" in computing operating expenses. Although this argument was rejected as inconsistent with the legislative history of the Act, the Court added that "[w]e do not say that the Commission lacks the authority to depart from the rate base method. We only hold that the Commission is not precluded from using it." Jackson again dissented in opposition to the reliance on the value of production properties in the rate base determination..$^{93}$

Eventually influenced by Mr. Justice Jackson's approach, the Commission adopted the field price concept in 1954 in passing upon the production component of the rates of an integrated producerpipeline. ${ }^{94}$ This conversion to the field price theory was probably occasioned by two factors. First, the company was able to convince the Commission that discovery was being deterred and "conservation in both production and use" was not being accomplished by the depressed prices resulting from the rate base method. ${ }^{05}$ The second factor influencing the Commission may have been its increased workload under the Supreme Court's decision in Phillips. ${ }^{90}$ With the spectre of having to set rates for all independent as well as integrated

90. Id. at 648 .

91. 324 U.S. 581 (1945).

92. Id. at 601 .

93. Id. at 610-11.

94. Panhandle Pipeline Co., 13 F.P.C. 53 (1954). The Commission's field price was based upon the "weighted arm's length prices" established by federally unregulated independent producers for similar gas in the fields. This price was multiplied by the volume produced and included in operating expenses.

95. Id. at 74-75.

96. Sce notes 68-70 supra and accompanying text. 
producers, the Commission may well have been searching for a more efficient method to dispose of rate cases than was possible under the traditional approach which required a case-by-case rate-base determination for each producer.

The Court of Appeals for the District of Columbia was not persuaded, however. Relying upon the Hope opinion, the court rejected the Commission's justification for converting to the field price method in City of Detroit $v$. Federal Power Commission.97 While the court admitted that "allowance of a field price for the utility's own produced gas as an element in the ultimate composition of rates is not unlawful merely because it departs from the traditional rate-base method," it held that the Commission had not justified its position in terms of protecting the consumer interest, its primary responsibility under the Act ${ }^{98}$ The court added that

it is essential in such a case as this that [the rate-base method] be used as a basis of comparison . . . . Uniless it is . . . used at least as a point of departure, the whole experience under the Act is discarded and no anchor . . . is available . . . to hold the terms "just and reasonable" to some recognizable meaning.99

On remand the Commission reverted to the rate-base method. ${ }^{100}$

The Fifth Circuit was confronted with a similar issue in Bel Oil Corp. v. Federal Power Commission. ${ }^{101}$ Agreeing essentially with City of Detroit, the court held that the evidence concerning typical field prices coupled with expert testimony asserting the need for an incentive price to encourage exploratory and development activity was insufficient to demonstrate that the resulting rates were just and reasonable. However, the court indicated that cost evidence might be sufficient in some circumstances to insure just and reasonable rates and suggested that the Commission need not fix separate rates for each producer if a uniform rate for the field was found to be more desirable.

Although these decisions involved integrated companies, they are equally applicable to independent producers. The real thrust of the opinions suggests that, in justifying an increase in rates, the traditional rate base computations must be used as a point of departure.

97. 230 F.2d 810 (D.C. Cir. 1955), cert. denied, 352 U.S. 829 (1956).

98. Id. at $815-17$.

99. Id. at 818-19.

100. Panhandle Eastern Pipe Line Co., 25 F.P.C. 784 (1961).

101. 255 F.2d 548 (5th Cir. 1958). 


\section{Evolution of the ArEA Approach}

The FPC's new jurisdictional coverage under the Phillips decision ${ }^{\mathbf{1 0 2}}$ required the regulation of interstate sales made by independent producers and was accompanied by the onus of an immense increase in administrative workload. Producer compliance with the Commission's order pursuant to the Phillips holding resulted in an enormous influx of applications for certificates of public convenience and necessity. ${ }^{103}$ Filing of the rate applications required by section 4 of the Act increased in like manner. ${ }^{104}$ This great regulatory morass signalled the need to seek another approach, especially since the courts had precluded the field price method.

An indication of a new approach arose in section 7 proceedings upon applications for certificates of public convenience and necessity. The Commission was faced with the responsibility of expeditiously handling countless license applications attributable to the enormous increase in the demand for gas ${ }^{105}$ while at the same time assuring a reasonable price for gas at the production level. If the licensing process had to await a section 4 rate valuation, the immediate demand for gas could not be met. A solution to the dilemma was found in section 7(e) of the Act which empowers the Commission to issue a certificate on "such reasonable terms and conditions as the public convenience and necessity may require." 106 In Cities Service Gas Co. ${ }^{107}$ the Commission conditioned issuance of a certificate upon establishment of a gas price at the production level not to exceed the price level prevalent in the area. Thus, the Commission successfully resorted to at least an average field price theory, although only as a

102. See notes 69-71 supra and accompanying text.

103. From 1942 to 1954 , the total number of certificate applications was 1,244 . In a single year following the decision, the FPC received 6,047 applications from independent producers alone. Connole, General Considerations: A Nation's Natural Gas Pains, 44 Geo. L.J. 555, 55960 (1956).

104. Prior to Phillips, the annual number of rate filings amounted to approximatcly $700.1 \mathrm{n}$ the first year after Phillips, utilities presented over 11,000 rate filings and 2,000 supplementary filings proposing either rate increases or modification of existing rate schedules. Id. By 1960, a large number of rate filings had accumulated awaiting final disposition. The supplements alone totalled over 33,000. GARFIELD \& LovejoY 330.

105. See Ross, The Area Rate Proceedings: An Unsettled Experiment in Public Control of Natural Gas Prices, 18 Sw. L.J. 165, 170 (1964).

106. 15 U.S.C. $\& 717$ f(e) (1964).

107. 14 F.P.C. 134 (1955). 
temporary measure to expedite licensing. The Commission's use of field price for this purpose was affirmed. ${ }^{108}$

The "CATCO" litigation, ${ }^{109}$ certainly an illustration of administration at its low ebb, resulted in an implicit affirmance by the Supreme Court of the Cities Service approach. The Commission had initially imposed conditions similar to those adopted in Cities Service. ${ }^{110}$ However, when the producers threatened to cancel their existing sales agreement and sell their 1.67 trillion cubic feet of gas in the intrastate market if the price conditions were imposed on interstate sales, the Commission capitulated and withdrew the conditions. ${ }^{111}$ The Supreme Court reversed, ${ }^{112}$ holding that the Commission was obligated to impose an initial price in the public interest when the price negotiated between the producer and the pipeline was significantly "out of line" with the general field price in the area of production.

Now clearly faced with both the burden imposed by Phillips and the onus of conditioning initial licensing to assure reasonable temporary rates pending a detailed section 4 proceeding, the Commission decided to undertake a wholly new approach. In 1960, shortly after the Supreme Court's decision in CATCO, the Commission announced its adoption of an area rate approach containing elements of both the rate base and field price methods. ${ }^{113}$

In detailing the reasons why the individual cost-of-service approach did not satisfy the objectives of effective regulation, ${ }^{114}$ the Commission specifically observed that return had no logical or rational relation to investment. In addition, the Commission noted that the cost-of-service approach provided no incentive or reward for the efficient, pioneering, or even lucky producer. Further, the individual cost-of-service approach created incentives toward sales policies that unfairly inflate the ultimate price to the consumer. First, the approach encouraged the producer to sell his highest cost gas to

108. Signal Oil \& Gas Co. v. FPC, 238 F.2d 771 (3d Cir. 1956), cert. denied, 353 U.S. 923 (1957). This case was decided between City of Detroit and Bel Oil. See notes 97 \& 101 supra.

109. CATCO is a term used to refer collectively to the oil companies involved in a series of related cases. Atlantic Ref. Co. v. Public Serv. Comm'n, 360 U.S. 378, 380 n.2 (1959).

110. Continental Oil Co., 17 F.P.C. 563, modified, 17 F.P.C. 732 (1957).

III. Continental Oil Co., 17 F.P.C. 880 (1957).

112. Atlantic Ref. Co. v. Public Serv. Comm'n, 360 U.S. 378 (1959). The Court's reasoning was very similar to that adopted by the FPC in Cities Service and the initial CATCO order.

113. Phillips Petroleum Co., 24 F.P.C. 537 (1960).

114. Id. at 544-47. 
the interstate market, saving gas produced at a lower cost to be sold in the unregulated intrastate market. In this manner, the firm could maximize its profit. Second, since royalties to the lessor of gasproducing lands are usually based upon a percentage of the price the producer eventually receives, the lessor would want to lease to the highest cost producers in order to maximize royalties. This practice placed significant upward pressure on prices generally by increasing the lease price to the more efficient producer.

Another problem detailed by the Commission was the difficulty of assigning joint costs between oil and gas and between intrastate and interstate gas. Under an individual cost-of-service approach, such allocation was crucial. Additional uncertainty arose from the virtual impossibility of predicting the quantity, quality, and resulting value of reserves for purposes of establishing the rate base. Finally, tax uncertainties presented significant problems in arriving at a unit cost.

Most significantly, the price determined by application of an individual firm cost-of-service method had no relationship to the value of the product to the consumer. For example, the Commission observed, much gas is produced from wells owned jointly by several producers. Since each producer had different overall costs, the price of units of gas from the same well varied tremendously depending not upon any difference in the gas but upon the cost characteristics of the particular producer-seller. Indeed, the Commission found in several instances that the firms were significantly underpricing their gas on a cost basis because the market would not support a price reflecting individual cost.

In addition to these economic arguments, the Commission relied heavily upon the administrative burden occasioned by application of individual firm cost-of-service to the multitude of independent producers. It concluded that

effective regulation of the price of natural gas must be on some more manageable plan that $[$ sic] the rate base method . . . . [T] would be to establish fair prices for the gas itself . . . based on reasonable financial requirements of the industry and not on the particular rate base and expenses of each natural gas company. ${ }^{\mathrm{It}}$

The Commission preliminarily designated twenty-three areas, noting that future inquiry into the appropriate economic and cost 
factors might cause a reorganization of the geographical divisions. ${ }^{116}$ In addition the Commission established interim area "rate guidance levels" based upon historic cost, demand, and price trends in the area to serve until the area proceedings could be concluded. ${ }^{117}$ The Commission then proceeded to terminate the individual producer investigations, many of them pending since the Phillips decision in 1954 , and set all of these cases for hearing under the new area rate approach.

Phillips Petroleum, whose rates were still awaiting final determination following the remand from the 1954 decision, contended that abandonment of the traditional method was not permitted by the Act. The Supreme Court, however, affirmed the order, permitting the Commission to proceed in working out the area approach..18 The Court stated that rigid adherence to a particular method of rate regulation to the extent that any other method was unlikely to be sustained "would be wholly out of keeping with this Court's consistent and clearly articulated approach to the question of the Commission's power to regulate rates." 119 The Court also affirmed the imposition of the interim rates but reserved final approval of the area approach until a completed area proceeding was brought before it for review. Nevertheless, the Court's recognition of the problem that the Commission was facing and its decision to let the agency experiment with the new approach were significant. ${ }^{120}$

The details of the area approach, as well as its underlying justification and legality, still remained for resolution in the area proceedings themselves. Sharp disagreement existed between producers, pipelines, ultimate consumers, economists, and the Commission's staff over these issues. The first forum for airing such disagreements before the Commission was the Permian Basin Area Rate Proceeding. ${ }^{121}$

116. FPC, Statement of Gen. Policy No. 61-1, 18 C.F.R. $\S 2.56$ (1970); 24 F.P.C. 818 (1960).

117. These interim rates did not purport to be "just and reasonable" rates. The guideline prices were of two types: "initial service rates" applicable to rates proposed for sales under new contracts and "increased rates" applicable to proposed increases in rates charged under existing contracts.

118. Wisconsin v. FPC, 373 U.S. 294 (1964).

119. Id. at 309 .

120. The Court stated: “We respect the Commission's considered judgment backed by sound and persuasive reasoning that the individual company cost-of-service method is not a fcasible or suitable one for regulating the rates of independent producers. We share the Commission's hopes that the area approach may prove to be the ultimate solution." Id. at 310 .

121. 34 F.P.C. 159 (1965). 


\section{The Permian Basin Case}

The Permian Basin is a major petroleum producing area underlying much of Western Texas and Southeastern New Mexico, rich in conjuctive gas and oil deposits, and accounting for approximately 11 percent of all gas moving in the interstate market. ${ }^{122}$ Prices for gas at the wellhead in the Permian region have historically been lower than those in other areas of the country for a variety of reasons. ${ }^{123}$ Most Permian gas is associated gas, the reservoirs composed of oil and gas at a volume ratio of two to one. ${ }^{124}$ Such gas usually is of lower quality than that in other areas. Moreover, the Permian Basin was discovered and substantially developed before the pronounced increase in prices experienced during the 1950's. Since costs are to some extent related to the value of the product, the original costs in the Permian area were probably relatively low, and this was reflected in field prices. Distance from the market had increased transportation costs and thereby held the field price down. In addition, prices in the Permian Basin, unlike many other fields, had already been subjected to substantial regulation since a relatively large amount of gas was produced by integrated pipeline producer firms. ${ }^{25}$

The Federal Power Commission's decision finalized the adoption of an area approach. Reiterating its view that rate determination based upon each individual firm's cost-of-service was both administratively unworkable and inconsistent with the goals of rate regulation, ${ }^{126}$ the FPC flatly rejected, however, the use of freely negotiated prices as the sole determinant of the proper rate. ${ }^{127}$ While the importance of adequate reserves was recognized, the Commission did not accept the argument that a low reserves-to-production ratio -justifies the existing and future contract prices, whatever they may be. $" 128$

122. Permian Basin Area Rate Proceeding, 34 F.P.C. 159, 173 (1965).

123. Id. at 174. See also NeUNER 125-26.

124. 34 F.P.C. at 173. The national average is one to two. Id.

125. Id. at 252-53 (Commissioner O'Conner's opinion, concurring in part and dissenting in part).

126. Id. at 179.

127. "[O]ur examination of the contract prices of the gas producers is only the beginning and not the end of our task in establishing the proper criterion for determining just and reasonable rates." Id. at 183.

128. Id. at 185. For an interesting sequel to the reserve-exploration incentive problems, see notes 206-22 infra and accompanying text. 
In general, the Commission adapted the individual firm cost-ofservice method in detailing its area approach. ${ }^{129}$ Utilizing the composite data at hand to figure the average cost of "plant" and the average expenses per unit of gas produced, the FPC then determined a fair rate of return and applied this to the average rate base. The result was a per unit price that would provide a fair return on the average investment and recovery of average expenses. This price was adopted as the maximum rate chargeable by any firm in the area. Thus, in theory at least, the new approach was still grounded on a cost-ofservice rationale. The Commission did mention that certain other factors might be relevant in the determination of the price for each particular area. "The factors which are commonly considered in the design of rates include the impact of the prescribed rate on existing rate structures, the quality of the gas in the area, the historical prices in the area and other such factors." 130 However, the Commission did not employ such non-cost factors in its Permian decision, ${ }^{131}$ but decided to use a multiple price approach, setting one price based upon historic costs for old gas-well gas ${ }^{132}$ and a higher ceiling price for new gas-well gas. The latter higher price was adopted to promote the exploration for, discovery of, and development of further reserves. This price incentive was not provided for "flowing gas," defined to include gas-well gas already dedicated to the interstate market by contract and oil associate gas whether dedicated or not, since this gas was either already discovered or exploration was so related to oil production that the price incentive would have little impact..$^{133}$

Although the rate on new gas-well gas had functional purposes not directly related to costs, the Commission adopted an objective

129. Pursuant to its order establishing the area rate proceedings, the Commission distributed questionnaires to all producers, soliciting information on cost and operating experience in both the particular area and nationwide. 26 F.P.C. 247, modified, 26 F.P.C. 514 (1961). It also announced that individual company costs of service evidence would not be received in the proceeding, but only composite industry and area cost studies. 25 F.P.C. 614 (1961), modifed, 26 F.P.C. 943 (1962).

130. 34 F.P.C. at 207.

131. Id.

132. Id. at 185-89. Originally gas moving under contracts filed with the Commission before January 1, 1961, and all associated gas was classified as old gas; gas-well gas moving under contracts filed on or after that date was new gas. Recently, however, the Commission has changed the application of the terms to provide an additional incentive to new discovery and production. Hugoton-Anadarko Area Rate Proceeding, Nos. AR64-1, 61-1, \& 61-2. FPC No. 567 , Oct. 3, 1969. See note 208 infra and accompanying text.

133. 34 F.P.C. at 208-12. 
standard based upon cost for determining the higher, incentive price. ${ }^{134}$ For this gas the Commission used the 1960 nationwide composite current costs. ${ }^{135}$ The Commission's uniform ceiling price for flowing gas, however, was based on the composite historic cost of the gas produced..$^{137}$ In determining the appropriate rate of return, the Commission was guided by the standard enunciated in Hope: a return sufficient to attract new capital in light of the risks inherent in the investment and sufficient to assure confidence in the financial integrity of the enterprise. ${ }^{138}$ Aware of the independent producer's unique market position and the risks he faces, the Commission established a 12 percent rate of return for new gas-well gas. ${ }^{130}$ The same rate was established for flowing gas, since the lesser risk involved in discovery was thought to be counterbalanced by the greater risk in the pronounced below-pipeline quality of flowing gas in the Permian Basin..$^{140}$ Through this process, the Commission arrived at a base ceiling price of 16.4 cents per thousand cubic feet $(\mathrm{Mcl}$ ) for new gas-well gas and 14.5 cents per $\mathrm{Mcf}$ for all other gas.

A nother issue considered by the Commission was whether the ceiling price should vary depending upon the quality of the gas. It concluded that since productivity is what is ultimately purchased, a differential is necessary to reflect the energy content of new gas-wcll gas. ${ }^{141}$ Sour gas, gas with impurities, costs the same as quality gas to

134. Id. at 185-88.

135. The Commission used nationwide, rather than area, data because exploration is carricd on nationwide, area data was incomplete or non-existent, and there was no indication that these costs were out of line with costs in the Permian Basin.

136. The most important components in the pricing of both old and new gas was the cost of exploration, development, and production. Other cost factors ultimately affect the regulated price, such as administrative and regulatory expenses, but their effect for purposes of this article is not significant.

137. Data on the actual cost of bringing forth the gas over the years were provided in the questionnaires returned by forty-two relatively large producers in the area in response to the FPC's request. See note 129 supra. The small producers, for the most part, failed to submit such statistics. 34 F.P.C. at 214. The hearing examiner determined historic costs somewhat differently, taking 1960 costs for new gas-well gas and back-trending them on the basis of evidence of price trends over the period. Id. at 212-13, 218-20. The Commission rejected this "estimate" approach in favor of the staff's actual data but did use the hearing examiners conclusions to check on the validity of the staffs conclusion. Id. at 212-13. The Commission found that the two different approaches resulted in strikingly similar ultimate cost estimates. Id. at 212.

138. 34 F.P.C. at 200.

139. Id. at 204.

140. Id. at 215 .

141. Id. at 223. 
discover and produce but is usually sold for less in the field because it will require refining. Moreover, a producer could circumvent the area price ceiling in practice if it could dilute the BTU content of the gas and still command the same price. The Commission determined the weighted average BTU content for gas-well gas in the Permian Basin and provided for upward and downward adjustments in price depending upon the premium or deficient nature of the gas. ${ }^{142}$ This is the one instance in which the Commission seemed to be relying on a value-rather than a cost-rationale. The Commission decided such a provision was unnecessary for flowing gas since similar treatment had bcen provided for in the existing contracts. ${ }^{143}$ Nothing indicated that the absence of such a provision in the rate order would affect price. The Commission stated, however, that the matter would be reconsidered if such an effect were later apparent. ${ }^{144}$

The Commission also established a minimum rate below which no interstate sale could be made, irrespective of existing contract terms. ${ }^{145}$ This was designed to rectify the situation whereby many producers had contractually precluded themselves from obtaining an increase in the price of their gas despite substantial increases in costs. Without a minimum price order, the Commission asserted, the lower priced gas would not pay its fair share of current costs and such loss would either have to be rccovered as part of the cost of gas not subject to such contracts or out of the investor's pocket. Either alternative would be inequitable to both investors and consumers of the higher priced gas. Moreover, prescription of a minimum rate was considered consistent with the theory underlying area rate regulation since it would encourage exploration and development activity by producers subjcct to such contracts who might otherwise have been deterred. Existing contract prices between the minimum and maximum set by the Commission were left intact. Any contractually permissible increase within this range required only that the firm file the new rate under the normal section 4 procedure. ${ }^{146}$

142. Id. at 221-25. Small producers were exempted from these price variations. Id. at 225 .

143. Id. at 221 . See also GARFIELD \& Lovejoy 343.

144. 34 F.P.C. at 223.

145. Id. at 231 .

146. Id. at 227-32. However, small producers, defined as those natural gas companies selling less than 10,000 Mcf annually in interstate commerce, were exempted from the rate increase filing requirements of the act so long as their new rates did not exceed the maximum. They only had to submit an annual report stating the total volume of jurisdictional sales and certify that all sales were made at prices at or under the area ceiling. Id. at 235-36. 
The Commission also proscribed favored nation and spiral escalation clauses in sales contracts in situations where exercise of these clauses would set the price above the applicable area ceiling.1.17 Finally, the Commission provided that any producer who was being injured as a result of the imposition of the area rate could petition for individual relief. ${ }^{148}$ The Commission did not specify the "exceptional conditions" which would merit relief from the area rate, noting only that complaints would be examined on a case-by-case basis. A moratorium of two and one-half years was imposed on filing of increases above the ceiling price ${ }^{149}$ to promote effective implementation of the area approach.

Perhaps the first step in analyzing the decision to adopt area pricing is to understand that the Commission retained a cost-ofservice approach at least to justify its actions-rather than utilize the value-of-service rationale proposed in Mr. Justice Jackson's Hope dissent. Even where a functional element was interjected into pricing by adoption of the multiple price proposals, the Commission carefully justified the approach on a cost basis. It simply used different costs to justify the different rates. Thus the new approach clearly fails to meet all of the stated objections to the individual firm cost-of-service method. Group rates do not provide a rational relationship between return and investment for individual firms. While the area approach may build in an incentive toward efficiency and innovation, it provides only a partial remedy for the problem of producer sales of lower cost gas to the intrastate market and ignores the problem of joint cost assignment. ${ }^{150}$ Although the approach minimizes the financial impact of reserve valuation on any one firm, it provides no greater certainty in valuing those reserves. Moreover, while the group method does avoid the anomaly of selling identical units of gas from the same well at different prices, it still establishes no direct

147. Id. at 236-37.

148. Id. at 227.

149. Id. at 227-31.

150. Because of the difficulty of apportioning costs between gas and oil, the Commission simply adopted gas-well gas costs as the assumed costs of associate gas. Reasoning that some of the costs would have to be attributed to and recovered by the sale of oil, the Commission asserted that the average cost of associate gas would not be higher and that the producers would not be hurt by this treatment. 34 F.P.C. at 212-13, 217-18. This argument seems persuasive to calm fears that the price was too low to meet producer costs on associate gas but raises the possibility that the maximum price might be too high and not adequately protective of the consumer interest. See generally Kahn, supra note 17, at 510-17. 
relationship between price and value to the consumer. Finally, the group method has no direct impact on the conservation problems which concerned Mr. Justice Jackson and does not purport to effect socially desirable end uses. Indeed, one commentator persuasively argued that the area price approach actually deters conservation. ${ }^{151}$

The area method does undoubtedly take great strides toward solving the administrative log jam besetting the Commission. While this may furnish the best justification available for the approach, it is neither cost nor value related except to the extent that the minor savings in administrative costs are passed on to the consumer both in the form of lower prices and a reduced drain on the federal budget. One suspects that the administrative problems may have dictated substantive policy with "the tail wagging the dog." Nevertheless, in view of the alternatives available to the Commission, administrative efficiency may be an adequate justification.

The Commission could have proposed no regulation at all or-what is the same thing-it could have adopted field prices. This "solution" is not totally satisfactory. Many, including the Commission and perhaps the Court, believe that competition does not in fact keep field prices at the lowest reasonable level. Once this conclusion is reached, the Commission must come up with some workable system of regulation. Second, whether one agrees with the decision or not, the Supreme Court held in Phillips that Congress commanded the Commission to regulate price. Moreover, the lower courts have held in Bel Oil and City of Detroit that use of field price-unless related in some explicit way to the public interest--does not satisfy this command. Since Congress has not responded to those decisions by amending the Natural Gas Act, the Commission would not likely try to get these decisions overruled even if a sufficient record assured success.

Obviously the Commission could not retain individual firm regulation. Some form of group approach, based either upon cost or value, was the only realistic alternative. While perhaps desirable in the abstract, a group approach based upon value raises very difficult problems since no readily available objective standard exists for

151. See Kitch $243,278-80$. Under the area approach, high cost gas will likely be left for future generations to produce, use, and pay for. This results in two ways: High cost drilling is deterred, and producing wells are likely to be capped earlier as the cost of extraction increases toward the end of the well's life; if the price of gas is held below its market value, it will be used for lesser uses, thus dissipating reserves available for future optimum uses. 
arriving at a result. Determining the social value of various kinds of service and deriving the price required to attain that service is virtually impossible. The additional problem of ordering priorities of use, often subject to the influence of competing political pressures, creates further complications. Moreover, the Commission would probably have to exercise some control at the distribution level to make such a pricing system work. Finally, the financial integrity of the producers would require consideration in order to avoid the problem of confiscation. Therefore, short of nationalization of the industry, cost must still be the major element in arriving at the minimum price. Economic prognostication, let alone the political system, is incapable of reconciling these diverse objectives on any kind of rational basis. At best, the Commission would intuitively set the price based upon what it thought was necessary to produce certain desired market phenomena. Such an approach could be evaluated only after the fact, which normally would be too late.

Perhaps one can appreciate the difficulty of a value oriented approach by trying to visualize a court reviewing the Commission's decision to determine whether a price is reasonable. The court could do little more than accept the Commission's word for the reasonableness of the relationship between the ends that the Commission sought and the price that it had speculatively set to achieve those ends. Future economists may be able to master these problems; at present, however, they are able to do little more than identify past mistakes and predict future developments in broad outline. This is not to suggest that the FPC should never let specific functional objectives alter the result of their pricing system. While the Commission did not utilize functional objectives in its Permian decision, it has subsequently employed some functional pricing..$^{152}$ In summary, the Commission's cost-based area approach satisfies some-but not all-of the theoretical economic objections to traditional pricing, provides an incentive for efficiency and innovation, relieves the burden on administration, and provides a reasonably workable, relative standard for testing reasonableness.

Moreover, assuming that the Commission possessed adequate and accurate cost statistics and that it makes price adjustments as these statistics change in the future, the results of the area approach should not be strikingly different from the results under freely bargained-for

152. See notes 208-22 infra and accompanying text. 
field prices if the field prices are truly competitively set. The field price under pure competition should be at or near the lowest price that will cover costs and provide the minimum profit necessary to attract capital. Under workable competition, the field price approximates estimates of long-run average costs. In either case, a firm with abnormally high costs would either have to take a loss or go out of business. It would be precluded from charging a price above the ceiling set by the lower cost firms. Certainly, regulatory price response may lag behind price changes in the marketplace. However, it seems probable that a regulated price ceiling based upon historic and current costs would not vary widely from a competitively-set ceiling, at least if the market situation were relatively stable. In fact, the regulated area rate may be higher since the Commission did not consider competitive pressures and gave the producers the benefit of the doubt on virtually every contested cost factor. This analysis, if valid, suggests that producer objection to the area approach was at least partially premised upon the producers' belief that field price is not rigidly limited by competition.

Professor Kitch has advanced the thesis that the Commission's approach is not traditional price regulation at all but a price freeze. ${ }^{153}$ Contending that the Commission's method was only rationalized in terms of costs, he asserts that the FPC was in reality freezing the price at the 1959-1960 level in order to hold down prices to ultimate consumers irrespective of cost or value considerations. Characterization of the Commission's approach as a price freeze, however, seems to obfuscate analysis. First, Professor Kitch's use of the term "price freeze" is unclear. If he was suggesting an absolute bar on price increases, he is correct that such action is unprecedented in normal regulatory ratemaking. ${ }^{154}$ However, except for the moratorium period, this conclusion is difficult to support. Indeed, Professor Kitch's later discussion is not consistent with this interpretation. The Commission did premise its price on cost and provided for price adjustments to meet future cost increases. While regulatory response to cost changes in the future may be delayed, the same could be said of any regulation of price and provides no reason to conclude that adjustments will not be made. The genuine nature of the

\footnotetext{
153. Kitch 244-46.
}

154. An absolute bar on price increases has been utilized only in emergency situations and in the case of agriculture and urban housing where price freezes were in response to overwhelming pulitical pressure ur dislucation caused by war. 
Commission's general commitment to a cost premise is illustrated by the variations found in the later area cases. ${ }^{135} \mathrm{lt}$ is too early to accuse the Commission of bad faith.

On the other hand, perhaps Professor Kitch meant that the value of the rate base was frozen, and therefore price would not be responsive to market needs and changes. While this is true for previously discovered gas, it is not valid for future discoveries except to the extent of regulatory lag in price increases attributable to increased costs. This interpretation is consistent with the rest of the Kitch article but is not consistent with his statement that such a "freeze" is unprecedented. All ratemaking under the cost-ofservice method freezes the rate base evaluation at its original cost. The only difference between the traditional use of such a "freeze" and that employed in Permian relates to the content of the rate base. In Permian the bulk of the rate base is made up of the exploration and development costs even though the product may not be sold for some years. While there is some legitimate question as to whether and how these costs should be capitalized, Professor Kitch does not seem to be concerned with that problem. Otherwise, the "freeze" on rate base is clearly consistent with traditional cost-of-service ratemaking, and his statement that this is unprecedented makes little sense. This is clearly not the kind of parity pricing involved in agriculture or the freeze on prices and rent invoked during wartime.

Whatever he meant by the term "price freeze," Professor Kitch does suggest some very persuasive objections to the area approach. His apparent solution, however, lies in eliminating regulation completely rather than in modifying the existing regulatory scheme. At this point in history, that argument must be addressed to Congress; it does not seem very helpful for the Commission's use. His primary concern is that regulation alters the natural relation between supply and demand and will therefore distort development of the most desirable policies within the industry in terms of both economics and conservation. This conclusion is based on the premise that the industry would operate reasonably competitively without regulation, thus bringing price, supply, and demand into an optimum relationship. Sufficient evidence to support this premise is lacking. In structural terms, the supporting economic analysis ignores important unique features of the gas industry which may affect the degree of

155. See notes 202-22 infra and accompanying text. 
competition. Similarly, the evidence supplied by actual conduct is inconclusive since it was collected while the market was in an abnormal period of growth. Moreover, there was no independent market to be used as a test after 1960 .

In affirming the Commission's adoption of a general area approach, the Court accorded the Commission what may well be an unprecedented discretion in dealing with the problems involved. The Court's position recognizes that Congress has ordered in general terms that the Commission should regulate rates. Within that mandate, the Court reasoned, the Commission can do whatever is necessary so long as the approach adopted bears some semblance of rationality and does not contravene any explicit prohibition in the Act or the Constitution. Professor Fuchs has referred to this position as the charter for a new administrative state. He notes that:

Two decisions ${ }^{\text {ss }}$ of the . . . Court in the 1967-68 Term, enlarging a trend which has been developing for some time, create a new basis for expanding the methods by which federal regulatory agencies may meet new problems. This foundation for extending authority and adapting administrative process to new issues involves a major realignment of judicial, agency, and legislative authority . . . . The agency operations which result, although they continue to have a statutory basis, may range considerably beyond those which the mandate of existing legislation can accommodate comfortably. ${ }^{157}$

With this in mind, we turn to a consideration of "whether the Commission may, consistently with the Constitution and the Natural Gas Act, regulate producers' interstate sales by the prescription of maximum area rates, rather than by proceedings conducted on an individual producer basis." 158 In affirming the constitutionality of the area, group-type regulation, Mr. Justice Harlan wrote for the majority:

[T]he Constitution does not forbid the imposition, in appropriate circumstances, of maximum prices upon commercial and other activities. A legislative power to create price ceilings has, in "countries where the common law prevails, been customary from time immemorial . . .." Its exercise has regularly been approved by this Court ... No more does the Constitution prohibit the determination of rates through group or class proceedings. This Court has repeatedly recognized that legislatures and administrative agencies may calculate rates for a regulated class without first evaluating the separate

156. In addition to the Permian Basin Area Rate Cases, Professor Fuchs is referring to United States v. Southwestern Cable Co., 392 U.S. 157 (1968).

157, Fuchs, The New Administrative State: Judicial Sanction for Agency Self-Determination in the Regulation of Industry, 69 CoLUM. L. REv. 216 (1969).

158. Permian Basin Area Rate Cases, 390 U.S. 747, 768 (1968). 
financial position of each member of the class; it has been thought to be sufficient if the agency has before it representative evidence, ample in quantity to measure with appropriate precision the financial and other requirements of the pertinent parties. 159

The cases relied upon by the Court had upheld wartime price and rent controls as well as the use of group rates in regulating the transportation industries. ${ }^{160}$ These cases clearly establish the general constitutionality of such action assuming that the method adopted is a rational method to regulate the particular industry. One difficulty with the Court's opinion is its failure to deal explicitly with this question of rationality except as the area approach was viewed as a solution to the burden of individual firm ratemaking. The Court had no legislative record upon which to premise its findings of rationality, so one must assume that reliance was placed upon the Commission's expertise and discretion. While a substantial argument can be made that the regulation does not serve the overall public interest, ${ }^{161}$ nothing compels the conclusion that the regulation is irrational. Given the Court's handling of such questions in the past thirty years, it is neither surprising nor unfortunate that the Court refused to settle this issue..$^{162}$

The more controversial section of the opinion is the Court's agreement that the area rate regulation is within the authorization of the Natural Gas Act. Although the Act probably did not originally envisage the group approach to regulation, such an approach was not precluded. Certain language in the Act describing those subject to its requirements was drafted in the singular, suggesting a requirement of individual regulation. ${ }^{163}$ However, the broader reading permitting

159. Id. at 768-69 (citations omitted).

160. See Chicago \& N.W. Ry. v. Atchison, T.\& S.F. Ry., 387 U.S. 326, 341 (1967) (railroad rates); New York v. United States, 33 I U.S. 284 (1947) (same); Bowles v. Willingham, 32 I U.S. 503 (1944) (wartime rent controls); Acker v. United States, 298 U.S. 426 (1936) (rate regulation of stockyards and packers); United States v. Corrick, 298 U.S. 435 (1936) (same); Tagg Bros. \& Moorhead v. United States, 280 U.S. 420 (1930) (same); United States v. Abilene \& S. Ry., 265 U.S. 274, 290-91 (1924) (railroad rates); New England Div. Case, 261 U.S. 184, 196-99 (1923) (same).

161. Note the argument by Professor Kitch, text accompanying note 153 supra.

162. This opinion may be qualified upon recalling that it was the Court, in the Phillips casc, that initially required the Commission to regulate the independent producers. While perhaps the Court should have reviewed that basic proposition, it correctly abstained from doing so on the level of constitutional interpretation.

163. For example, section 5(a) of the Natural Gas Act of 1938 provides that

[W] henever the Commission . . . shall find that any rate . . . collected by any naturalgas company in connection with transportation or sale of natural gas . . . is unjust ... , [the Commission] shall fix the same by order: Provided, however, That the 
group regulation may be justified by interpreting the Act, as the Court did, ${ }^{164}$ to impose its obligation severally upon each producer. While the legislative history is inconclusive on this point, ${ }^{165}$ it seems reasonably clear that Congress never considered the question. The Court found support for area type regulation in the broad purpose of the Natural Gas Act. Reasoning that the Commission's authority must be broad enough to enable it to achieve those purposes, ${ }^{166}$ the Court stated that the Commission's broad and increasing responsibilities demand a "generous construction of its statutory authority." 167 Moreover, the Court noted, the Commission should not be limited by its past regulatory practices if new methods better serve the ultimate purposes of the Act. ${ }^{168}$ Rejecting the producers' contention that Hope had implicitly proscribed area rate regulation, the Court contended that the Hope decision merely repudiated "the suggestion that courts may properly require the Commission to employ any particular regulatory formula or combination of formulae." 169

As noted earlier, individual firm ratemaking was not accomplishing the purposes of the Act. ${ }^{170}$ The administrative burden had become so great that the cost in time and money defeated the very purpose of regulation. The Commission's choice as a practical matter was between some form of group regulation or no effective regulation at all. Moreover, it is questionable whether individual firm cost-of-

Commission shall have no power to order any increase in any rate contained in the currently effective schedule of such natural-gas company . . . . IS U.S.C. $\$ 717$ (1964)

(emphasis added).

164. 390 U.S. at 774 .

165. See Hearings on the Public Utility Act of 1935 (H.R. 5423) Before the House Comm. on Interstate and Foreign Commerce, 74th Cong., 1st Sess., pts. 1-3 (1935); Hearings on H.R. 11662 Before a Subcomm. of the Comm. on Interstate and Foreign Commerce, 74th Cong., $2 \mathrm{~d}$ Scss. (1936); Hearings on H.R. 4008 Before the Comm. on Interstate and Foreign Commerce, 74th Cong., Ist Sess. (1937); Hearings on Public Utility Act of 1935 (S. 1725) Before the Senate Comm. on Interstate Commerce. 74th Cong., I st Sess., pt. 1 (1935).

166. The Court cited the Commission's extensive authority under section 16 of the Natural Gas Act, 15 U.S.C. $\S 7170$ (1964), which provides that the Commission "shall have powcr to perform any and all acts, and to prescrihe . . . such order, rules, and regulations as it may find necessary or appropriate to carry out the provisions" of the Act. 390 U.S. at 776 n.40.

167. 390 U.S. at 776.

168. "It follows that rate-making agencies are not bound to the service of any single regulatory formula; they are permitted, unless their statutory authority otherwise plainly indicates, "to make the pragmatic adjustments which may be called for by particular circumstances."' id. at 776-77, citing. FPC v. Natural Gas Pipeline Co., 315 U.S. 575, 586 (1942).

169. 390 U.S. at 775.

170. See notes 102-04 supra and accompanying text. 
service regulation arrives at a price that serves the public interest in an industry with at least some competition. In similar situations, rates are usually set on a group basis. ${ }^{171}$ Thus, in terms of the economics of producer regulation, some form of group ratemaking seems desirable if one assumes, as the Court did, that the Act demands rate control. The Commission's position that exploration and development would be enhanced by calculating the needs of the industry as a whole rather than that of each firm seems particularly persuasive. Finally, group rates promote efficiency by providing an incentive to the efficient, lower cost firm. The individual firm cost-of-service approach generates considerably less incentive to economize since full costs-even those of inefficient firms - can frequently be passed on to the consumer.

The Commission's adoption of a dual rate approach is reasonably adapted to balancing the relevant competing public interest considerations-maintaining reasonable current prices to consumers while assuring future supply by providing an incentive for exploration and development of new reserves. Given the Court's generous reading of the statutory grant of discretion, the adoption of this kind of functional pricing structure is well within the Commission's power, at least where it can be cost related as was feasible here. The extent to which this cost relation is necessary is not clear from the Court's opinion. The Court implicitly upholds functional pricing even without the cost relationship so long as the Commission can justify it on some public interest basis. ${ }^{172}$ If this is true, the Commission might have shown greater candor in its opinion if it had openly discussed the level of income necessary to induce the needed supply irrespective of cost and set prices accordingly. The Commission may be adopting this approach; ${ }^{173}$ however, one must remember that the Commission had no indication that functional pricing would be permitted. Indeed, the courts of appeals had previously indicated that the rates must be costrelated, at least to some extent. ${ }^{174}$

Dual pricing, or price discrimination, to serve competing goals of regulation has long been permitted in regulated industries including gas transmission and distribution. No apparent reason precludes its use when gas production is the subject of regulation. One

171. The closest analogy is probably transportation rates. See GARFIELD \& LOVEJOY 79-80.

172. See 390 U.S. at 795-800.

173. This development is discussed more fully at notes 206-22 infra and accompanying text.

174. See notes 97-101 supra and accompanying text. 
commentator has suggested that the dual pricing structure adopted by the Commission might violate the Robinson-Patman Act, ${ }^{175}$ but this questionable criticism was not mentioned in the Court's opinion.

A more important criticism is that the dual price system will not provide the needed incentive for further exploration. For the individual firm, of course, the prices received are lumped together to arrive at the income available for new exploration. A higher price for either old gas or new gas would generally provide more money for this purpose. While supply is to some extent responsive to price, the exact price and concomitant income required to elicit the needed supply is uncertain. The Commission obviously thought that its cost-related figures were sufficient, but this apparently has not proved true. ${ }^{176}$ The multiple rate does, however, provide an added incentive for firms to find and market new gas since the price is higher. Although this may enhance exploration, it probably also means a loss in the conservation of already committed gas, depending upon the cost relationship for each individual firm's new and old production. Therefore, prediction or evaluation of the effect of the Commission's decision is extremely difficult.

Accepting the validity of the Commission's general approach and the Court's deference to Commission discretion in its adoption, the next inquiry is whether the rates actually set return sufficient revenue to satisfy the reasonableness standard of the Act and the due process standard of the Constitution. On the basis of the evidence in the record, the Court found that the rates met the Act's test of reasonableness ${ }^{177}$ and that the constitutional standard was identical to the standard established by the Act. ${ }^{178} \mathrm{Mr}$. Justice Harlan did add a cautionary note: "We do not suggest that maximum rates computed for a group or geographical area can never be confiscatory; we hold only that such rates ... intended to balance ... the investor and consumer interests are constitutionally permissible."179 If the producers could show that the rates returned less than full costs to a large number of producers over a long period, a very serious possibility of an unconstitutional "taking" would arise. The producers, however, were unable to show that the rates would be

175. Kitch, The Permian Basin Area Rate Cases and the Regulatory Determination of Price, 116 U. PA. L. Rev. 191, 215-20 (1967).

176. See notes 206-22 infra and accompanying text.

177. 390 U.S. at 822.

178. Id. at 770, citing FPC v. Natural Gas Pipeline Co., 315 U.S. 575, 586 (1942).

179. Id. at 770, quoting, FPC v. Hope Natural Gas Co., 320 U.S. 591,603 (1944): 
confiscatory in this overall sense. Until such proof is available, the cost data utilized by the Commission appear adequate to allow the establishment of a rate meeting the "just and reasonable" standard of the Act. As long as the Commission continues to perfect its accumulation of cost data by requiring more complete and comprehensive reporting accompanied by necessary price adjustments, this regulation is unlikely, as a matter of general application, to come within the proscription of an unconstitutional taking.

The producers also raised the constitutional objection that a particular firm's property may be subject to confiscation when the firm operates at costs above the composite costs used in arriving at the area rate. The Commission answered that:

The cases do not support the producers' contention that a just and reasonable rate fixed on the basis of the overall costs and profits of the producers in the area would be constitutionally confiscatory as to any respondent who could support a higher price on an individual company cost-of-service basis. ${ }^{180}$

The Court stated that a regulation is not necessarily a "taking" even though one may operate at a loss as a result; ${ }^{181}$ high cost operators have no constitutional objection merely because they are more seriously affected than others. ${ }^{182}$ The Constitution requires only that there be no "taking." Thus the firm cannot be required to operate indefinitely at a loss. But short of this, it is permissible to require firms to operate at lesser profits or-because of the interrelation of value and return-even to suffer a dimunution in the value of the firm. Thus, to provide an incentive to efficient operation, a price may be set that will cause high cost firms either to economize or cease operations

Nevertheless, if an individual company was operating at a loss, a serious constitutional question would be presented unless some means were provided by which the producer could be relieved. In the usual situations, such an entrepreneur may simply go out of business. The Natural Gas Act, however, requires Commission approval for any abandonment or transfer of interest. ${ }^{183}$ The Commission in Permian declared that a producer should be permit ted appropriate relief, either in the form of a waiver of the maximum price or permission to

180. 34 F.P.C. 159,179 (1965).

181. 390 U.S. at 769 .

182. Id. at 769-70. See generally Note, Rate Regulation-Area Pricing-FPC Area Price Regulation of Gas Producers Upheld, 42 N.Y.U.L. REv. 779 (1967) for a brief, but thorough, discussion of this issue.

183. Natural Gas Act $\S 7,15$ U.S.C. $§ 717 \mathrm{f}(1964)$. 
abandon operations or sell the business, if its "out of pocket expenses in connection with the operation of a particular well exceed its revenue from the well under the applicable area price." ${ }^{184}$ With the exception of this statement, the FPC opinion is vague and lacks any specific enumeration of the particular circumstances in which relief might be given, Concluding that the Commission's technique to enable the producer to get out of the business had not been shown to be inadequate, the Court left the question open for future consideration in a case in which the Commission's provisions for special relief were inadequate or unreasonably delayed. ${ }^{185}$ No specific evidence was presented to indicate that the price set would result in loss operations for any particular producer. Thus any more precise treatment of this matter was probably impossible and would have been premature.

This analysis, however, manifests two problems. First, efficient operation is only partially responsible for variations in cost. These variations result in substantial part from differing accounting treatment of joint costs and, more important for present purposes, from the operation of chance in exploration and development. Therefore, to say that a producer operating at a loss is doing so as a result of his inefficiency is not necessarily true. Rather, his loss is perhaps attributable to the happenstance of exploration and development. In addition, the firm may be producing from wells that are nearing depletion and are consequently more costly. It would be uneconomical, in the interest of long-run conservation, to force abandonment of wells before complete depletion. In these ways, the area approach may penalize some producers as well as consumers for matters over which they have little control. This uncertainty in exploration and development may differentiate the gas production industry from other situations in which group ratemaking has been

184. 34 F.P.C. 159, 226 (1965).

185. The court of appeals had reversed in part because the Commission had not articulated sufficient standards concerning the grant of relief by waiving the maximum price or permitting abandonment. Skelly Oil Co. v. FPC, 375 F.2d 6, 30 (10th Cir. 1967). The Supreme Court, however, found sufficient the Commission's recognition of the problem and intention to deal with it as such situations arose. 390 U.S. at 772 . The Court specifically noted the experimental nature of the proceeding and the absence of any clear indication concerning the nature of problems that might arise. Moreover, the Court felt that the general stay of the Commission's order imposed by the appellate court was unnecessary to protect firms that might present such problems. Rather, it assumed that stays would be granted in each instance by the Commission as the necessity arose. Id. at 772-73. The Court stated: "We therefore decline to bind the Commission to any inflexible obligation; we shall assume that it will, in situations in which stays prove appropriate, properly exercise its statutory authority." Id. at 773-74. 
found desirable. In general, however, the countervailing argument of administrative simplicity and feasibility overrides this infirmity so long as the firms operating at an overall loss have a means for getting relief. Moreover, the approach is still of an experimental nature and will undergo significant modification in the future as specific problems are brought to the Commission. Mr. Justice Harlan alluded to this possibility: "Finally, we must emphasize that we understand the present proceeding to be merely the first of many steps toward a more expeditious and effective system of regulations." ${ }^{186}$

Second, the Court's position assumes that the data upon which the rates were based were fairly representative. The producers had contended that the cost data used were not sufficiently representative to ensure that the price set was reasonable. The cost data used by the Commission in Permian and the subsequent area cases ${ }^{187}$ came principally from the larger and presumably more efficient firms. Distortion may result if these costs are used in arriving at the area price. However, the firms supplying the information did represent a large proportion of total sales volume; ${ }^{188}$ thus, even assuming drastically different costs, the average or composite industry costs would not have been affected greatly. Moreover, it is somewhat disingenuous for the producers to blame the Commission for the failure of many producers upon whose behalf the argument was being made to supply the data.

The use of industry average costs raises a more fundamental question. Mr. Justice Douglas' dissenting opinion in Permian adamantly attacked the use of average costs in determining the rate structure for all producers, ${ }^{189}$ contending that such a method was improper both in theory and as applied. Maintaining that "averages are apt to take us with Alice into Wonderland," he cited examples of the deception perpetrated by their use. ${ }^{190} \mathrm{He}$ objected most strongly that industry-wide average cost figures fail to account for differences

186. 390 U.S. at 772 n.37.

187. See Southern Louisiana A rea Rate Proceeding, No. AR61-2, Op. No. 546 (FPC, Sept. 25, 1968); Other Southwest Area Rate Proceeding, No. AR67-1, (Sept. 22, 1969) (Hearing Examiner's initial decision); Hugoton-A nadarko Area Rate Proceeding, No. AR64-I (Sept. 16, 1968) (Hearing Examiner's initial decision); Texas Gulf Coast Area Rate Proceeding, No. AR64-2 (Hearing Examiner's initial decision, Sept. 16, 1968); cf. Pipeline Production Arca Rate Proceeding, No. R P66-24, Op. No. 568 (FPC, Oct. 7, 1969).

188. See Permian Basin Area Rate Proceding, 34 F.P.C. 159, 213-14 (1965).

189. 390 U.S. at $829,833-37$.

190. Id. at 835-36. 
in the performance of companies attributable to size differentials. Advocating the use of typical, representative group costs, ${ }^{191}$ he recommended narrowing the determination into subclasses in order to obtain a more correct rate structure. His approach may ultimately be considered by the Commission if practical results in the first years of area regulation indicate that use of single average costs rewards larger producers to the detriment of the small producers.

These problems facing the small producer who attempts to operate within the confines of the area merit consideration. The large producer has significant cost advantages due to the economies of scale that exist in this aspect of the industry, particularly in exploration and development where the large integrated oil producers maintain sizeable staffs to prepare detailed geological information. The small producer, on the other hand, is forced to operate at a much riskier level and expend capital on more speculative ventures. To gear the cost evidence to the large producer may be inequitable to the small producer. Since the industry may approach oligopoly, at least as to its conduct, ${ }^{192}$ any regulation should clearly have as one of its ultimate purposes the maintenance of the competitive aspects of the industry unless such regulation is shown to result in significant subsidization of inefficient operations. The retention and encouragement of small producers could assure some measure of competition. However, the current decision may favor the large producer, and the ultimate effect is to create a spiral toward increased oligopoly. Small, independent producers will be forced to abandon operations or sell to larger firms if they cannot meet their costs. Even if the small producer can meet these costs the question remains whether he can obtain enough capital to engage in further exploration and development to secure needed reserves.

Nevertheless, area rates do not appear to leave the small producers in a significantly worse position than if field price were used or if there were no regulation at all. In these circumstances the small producer would have to sell at a competitive price set primarily on the basis of the costs of the larger producers. It would probably not be able to secure a price that reflected its higher costs. Even though this situation apparently existed prior to the area proceedings, ${ }^{193}$ small producers do not seem to have been abnormally deterred from

191. Id. at 834-35.

192. See note 24 supra and accompanying text.

193. See the Hearing Examiner's opinion appearing in 34 F.P.C. at $360-63$. 
entering the business. Moreover, the "disadvantage" is further alleviated by the exploration assistance given small producers by the large producers as a method of spreading risk. ${ }^{194}$ There is no reason to believe that the area rates will change this form of subsidy.

Finally, the overall affirmances by the Court included approval of the rate of return adopted by the Commission. ${ }^{195}$ The Court noted that substantial evidence suggested that this rate would allow the producers "to 'maintain financial integrity, to attract capital, and to compensate investors for the risks assumed" "186 without being excessive. ${ }^{197}$

The remainder of the Court's opinion dealt with the relatively minor rulings that the Commission had found necessary to implement its overall plan. Thus the Commission's discretionary inclusion of quality variations as a risk of production was upheld since it was accompanied by adequate findings concerning the revenue consequences of the variations. ${ }^{198}$ The Court held that the two and one-half year moratorium imposed by the Commission upon the filing of proposed rate changes was within the authority granted under sections 5 and 16 of the Act, reasoning that this "brief" period was necessary to achieve the agency's purpose in implementing area rate regulation. ${ }^{199}$ In upholding the prohibition of price increases pursuant to escalation clauses exceeding the area maximum, ${ }^{200}$ the Court stated
Although the Natural Gas Act is premised upon a continuing system of private contracting, ... the Commission has plenary authority to limit or to proscribe contractual arrangements that contravene the relevant public interests. ${ }^{201}$

Once again the Court deferred to the Commission's discretion and the clear authority of the Commission to alter contract terms under section 5(a). It pointed to evidence in the record that such price levels were not cost-related and therefore were not consistent with the publie interest. Exemption of the small producer from the filing

194. See text accompanying note 31 supra.

195. 390 U.S. at 808 .

196. Id.

197. Id. A reasonable argument can be made that the Commission was overly generous. See Kitch, supra note 54, at 201-02. The FPC staff, as well as public intervenors, argued for a much lower rate. See 34 F.P.C. at 200-04.

198. 390 U.S. at 811 .

199. Id. at 781 .

200. Id. at 781-84.

201. Id. at 784 . 
requirements was approved as a proper exercise of the Commission's statutory responsibility, especially in light of the resulting decrease in administrative burdens for both the Commission and the firms..$^{202}$ The cost saving to the firms, the Court reasoned, would partially counterbalance their higher operating expenses.

\section{Post-Permian Developments}

The Commission's subsequent opinion in one other area case ${ }^{203}$ and tentative decisions by Hearing Examiners in three more independent producer cases ${ }^{204}$ warrant brief consideration. First, in response to widely divergent cost data among the fields in the area, the Hearing Examiner in the Other Southwest Area case set different price ceilings for each of three sub-areas. Second, and perhaps more importantly, the Commission in the Southern Louisiana A rea case adopted a three-tiered price ceiling: one price for gas discovered before 1960; another price for gas discovered between 1960 and 1968; and a third price governing future discovery. This pricing scheme is attributable to the fact that most discovery in this area is offslore and entails greater expenditures for exploration and production. Finally, in considering whether to apply the area rates to pipeline producers, the Commission divided the proceeding into two phases: phase one to consider new gas-well gas prices and phase two to consider other gas. Although the Hearing Examiner generally concluded in phase one that the area price system should not be applied, ${ }^{205}$ the Commission has now reversed his decision and, absent court intervention, the area prices will apply to pipeline production of gaswell gas.206

In the fall of 1969 , a series of relatively minor FPC orders indicated an extremely significant shift in policy. The orders reflected the FPC's realization that exploration for and development of new gas supplies had fallen significantly below the level necessary to serve the gas needs of the very near future as was documented in an October

202. Id. at 787 .

203. Southern Louisiana Area Rate Proceeding, Dkt. No. AR61-2, Op. No. 546 (FPC, Sept. 25,1968 ). A partial rehearing was held in September, 1969. The issues on rehearing were recently expanded to include virtually the entire case. Offshore Southern Louisiana Area Rate Proceeding AR69-1 (FPC Déc. 15, 1969).

204. Other Southwest Area Rate Proceding, Dkt. No. AR67-1 (Sept. 22, 1969); HugotonAnadarko Area Rate Proceeding, Dkt. No. AR64-1 (Sept. 16, 1968); Texas Gulf Coast Area Rate Proceeding, Dkt. No. AR64-2 (Sept. 16, 1968).

205. Pipeline Production Area Rate Proceeding, Dkt. No. R P66-24 (Mar. 3, 1969).

206. Pipeline Production Area Rate Proceding, Dkt. No. RP66-24, Op. No. 568 (FPC Oct. 7, 1969), rehearing denied, Op. No. 568-A (FPC Dec. 5, 1969). 
1969 report by the Commission's staff. ${ }^{207}$ Predicting that if present trends continued the nation would face a significant gas shortage problem by 1973 , the report noted the decline in the reserve-toproduction ratio since 1946.

Despite this decline, the study reported, new additions to reserves had always exceeded production until 1968. In 1967, for example, discoveries totalled 21.1 billion $\mathrm{Mcf}$ in comparision to production of 18.4 billion Mcf. But in 1968, only 12.0 billion Mcf of new gas were discovered, while production totalled 19.3 billion $\mathrm{Mcf}$. The study also reported that consumption had been increasing at a steady rate of six percent per year with no indication of a future decline. At this rate, the entire discovered supply would be exhausted in only a few years. Indeed some pipelines have had to withdraw recent applications for permits to expand because they were unable to secure a commitment for an adequate supply of gas. ${ }^{203}$ Yet substantial evidence indicates that the potential supply of natural gas is adequate. ${ }^{200}$ It scems obvious that the pricing mechanism established by the Commission in the area cases is not inducing the needed level of exploration and development.

Within a week after the staff report was released, the Commission issued two opinions attempting to enhance the incentive for increased exploration and development under the area rate concept. First, the Commission decided that classification of gas-well gas as "old" or "new" would be based on the date of discovery of the particular reservoir, rather than the date upon which the production from the relevant acreage had been contractually dedicated to interstate commerce. ${ }^{210}$ This decision potentially may encourage firms to explore for new reservoirs within areas where gas is already being produced through both increased exploration around a known reservoir and through attempts to find gas at greater depths. Although to some extent this extcnsion of the higher rates for new gas can be cost-justified, the Commission scemed primarily concerned with providing a greater incentive for finding and providing such

207. FPC bureau of Natural Gas, Staff Report on National Gas Supply and Demand (1969). See also O'Conner, Gas Supply and the Role of the Independent Producer, 84 PUB. Util. Fort. 26 (1969); Fortune, Nov. 1969, at 120; Address by Commissioner Bagge, The Institute of Gas Technology, Oct. 30, 1969.

208. Address by Commissioner Bagge, supra note 207.

209. FORTUNE, Nov. 1969, at 121 .

210. Hugoton-Anadarko Area Rate Proceeding, Dkt. No. AR64-1, Op. No. 567 (FPC Oct. 3, 1969). 
gas-a functional justification. Second, the Commission applied area rates to new gas-well gas produced by pipelines. ${ }^{211}$ This decision will allow most pipeline producers to secure higher returns under the area rates than they could justify under the individual firm, cost-of-service approach. While the change to area rates could probably have been at least partially justified on more traditional grounds, the Commission's essential rationale apparently eschews such justification and notes:

In light of an apparent gas shortage, we are concerned whether the pipelines will make an increased effort to explore for and develop new gas reserves. We are also concerned whether new gas supplies will be available to the consumers of gas served by the long pipelines. To attain these ends, it may be incumbent upon us to modify traditional approaches to regulation with respect to pipeline production in order to provide a regulatory climate conducive to an aggressive pipeline exploration program. ${ }^{212}$

In responding to the possible charge that such rates were not costpremised within the mandate of City of Detroit, ${ }^{213}$ the Commission asserted that

clearly the "anchor" [the rate-base method] the court there felt should be the "point of departure" in moving to a pricing system other than the conventional rate-base method ... lies in the approved just and reasonable area rates approved for independent producers. ${ }^{214}$

On December 15, 1969, the Commission issued a very significant order reopening the rate level question in virtually al] areas. ${ }^{215}$ On a petition for rehearing earlier that year, the Commission had decided to reopen the question of the proper rate ceiling for new gas from the offshore Louisiana area in the federal domain. ${ }^{216} \ln$ its December 15 order, however, the Commission extended this reappraisal to prices on all gas in the Southern Louisiana Area, onshore and offshore, irrespective of the contract date.

Equally important was the Commission's response to a request for a nationwide proceeding to re-examine all the area rates. Although the

211. Pipeline Production Area Rate Proceeding, Dkt. No. R P66-24, Op. No. 568 (FPC Oct. 7, 1969), rehearing denied, Op. No. 568-A (FPC Dec. 5, 1969).

212. Id. at 4.

213. See notes $97-101$ supro and aecompanying text.

214. Pipeline Production Area Rate Proceeding, Dkt. No. RP66-24, Op. No. 568, at 7 (FPC Oct. 7, 1969).

215. Offshore Southern Louisiana Area Rate Proceeding, Dkt. No. AR69-1 (FPC Dec. 15, 1969).

216. Southern Louisiana Area Rate Proceeding, Dkt. No. AR61-2, Op. No. 546-A (FPC Mar. 20, 1969). 
Commission refused immediate re-examination of the area rates, reasoning that rates still pending in active cases should be determined first; it expressed sympathy with the request for a review of the Permian maximum and stated that the matter would be carefully considered. These developments indicate that a major shift in the Commission's approach to the area rates has been triggered by the low level of exploration and development.

Finally, two related actions by the Commission indicate a change in its treatment of research and development expenditures. Traditionally requiring that such expenditures be capitalized as part of the rate base, the Commission recently permitted two firms to write off the cost of their participation in Project Wagon Wheel and Project Rusilon as an expense. ${ }^{27}$ Then on January 27, 1970, the Commission announced a rule-making proceeding whose purpose was explained by one Commissioner thus:

The incentive needed for greater $R \& D$ [research and development] activity by jurisdictional companies lies in providing a greater degree of certainty regarding the effect of $R \& D$ investment on the financial position of the company and in enlarging the area of managerial discretion with regard to the accounting treatment of such expenditures within the regulatory framework.

Consequently, just last month the Commission issued in Docket No. R-381 a proposed rulemaking delineating proposed amendments to the Uniform System of Accounts intended to clarify Commission policy on accounting for $R \& D$ expenditures. These amendments recognized the need to establish a greater degree of certainty in the Commission's ratemaking and accounting policies, the need to allow a return on significant expenditures for special research and development projects amortized over a period of years and the recognitition that so-called "unsuccessful" projects pave the way for "successful" projects and as such should be regarded as part of the total research and development effort. This policy should place jurisdictional companies on a more equal footing with the non-regulated sector in competition for capital investment in $R \& D$ particularly where projects involving significant expenditures are concerned.218

While it is difficult to appraise the developments at this point, one can predict with fair certainty that the Supreme Court would affirm these changes. The Permian case seems to permit functional pricing if it can be justified on a public interest basis ${ }^{219}$ presumably including a

217. See Letters from FPC to El Paso Natural Gas Co. and Colorado Interstate Gas Co., Jani. 9, 1970 (reported in FPC News, Jan. 9, 1970, at 6). The projects involved application of nuclear technology to release gas from deep strata.

218. Address by Commissioner Carl E. Bagge, Midwest Gas Assoc., Feb. 24, 1970.

219. See note 172 supra and accompanying text. 
situation of declining supply. But whether the Commission should, as a matter of policy, respond to this evidence by setting higher, noncost-related maximums is more questionable. Analysis of this issue requires identification of the causes of the decline in new discovery. The producers, as would be expected, contend that the rates set by the Commission are so low as to provide little or no incentive for firms to allocate funds to new exploration. However, this contention is selfserving; the firms could, as has been charged ${ }^{220}$ drop their exploration efforts temporarily or furnish misleading information hoping to convince the Commission to raise the price. The substantial drop in 1968 coincided with the culmination of the Permian litigation and the potential opening of proceedings to examine the adequacy of the rates set on the basis of 1960 experience. In addition, the other rate cases were all reaching the final decision stage in the Commission, and a change of administration was imminent.

It is somewhat difficult to believe, however, that the entire decline in discovery and exploration was intentionally created to force the Commission to sanction higher rates. First, the cooperation and coordination necessary to achieve such massive inaction throughout the industry is unlikely to have gone unnoticed. Second, the amount of exploration had been dropping steadily for several years previously, ${ }^{221}$ 1968 only marking the most severe decline. However, some concerted effort possibly occurred. The reserve figures furnished to the Commission by the American Gas Association, an organization of pipelines and distributors, are stated in general terms without specification, breakdown, or explanation of methodology. Short of requiring the firms to furnish specific information, the Commission has no way of checking the accuracy of the Association's statistics. Curiously, the FPC has refused to demand such information despite its apparent importance. ${ }^{222}$ If a cooperative decision to delay exploration or to furnish misleading data is at least a partial cause of the decline in discovery, the Commission should move very slowly in

\footnotetext{
220. See ForTUNE, Nov. 1969, at 120, 189; Address by Commissioner Bagge, supra note 207

221. Through 1967 the amount of new reserves added annually had remained constant. However, as the decline in the production-reserves ratio illustrates, the addition of new reserves had not kept pace relative to production. See FPC BUREau of Natural Gas, Staff RePort ON National Gas Supply aNd Demand 11 (1969). Moreover, the number of completed wells had been decreasing steadily, FortunE, Nov. 1969, at 120, 189, as had the number of wells drilled. StafF REPORT, supra, at 35 . What is really needed, however, are statistics on total expenditures relative to cost for exploration over recent years. No reliable data were available.

222. See Address by Commissioner Bagge, supra note 207.
} 
responding with higher incentive rates. Otherwise, regulation would be meaningless. Functional pricing has no standard for evaluation except past performance. This standard is meaningless if the regulated firms are not operating in good faith.

There are, however, other possible explanations for the decline in discovery and exploration. The first is that the firms are not in fact receiving an adequate return and the rates should be raised. Three factors support this position: a sharp increase in exploratory drilling costs; the increase in general interest rates and overall financing expenses; and a shortage of current assets due to the refunds ordered in conjunction with the area rate cases. The Commission's action in permitting more flexible treatment of exploratory costs should help alleviate the first of these problems. The third factor is a temporary phenomenon and should properly be relieved by some form of Commission action. However, a general increase in rates does not appear to be the correct solution. The second factor, related to the general inflationary problem, is somewhat more difficult to counter. A higher rate for gas would only add to that inflationary pressure. The industry may be exhibiting the typical resonse to the antiinflationary pressure to cut back spending and expansion. If so, the result is temporary, and one that should, in terms of the aggregate economy, be desirable. However, as in the housing industry, a future shortage is a high cost to pay for this anti-inflationary adjustment. Whether, under these circumstances, the Commission should respond by raising rates presents a real dilemma calling for a careful weighing of the ability of the firms to supplement depleted reserves in the future against the overall inflationary effect of a rate increase.

Other factors may also be involved. The stagnant nature of the current domestic oil market and the massive investment of firms in exploratory efforts abroad and in Alaska probably affect gas exploration. Gas normally obtained as a side product of domestic oil exploration is lost, and money which could be spent on directional gas exploration is channeled to non-domestic oil exploration. Absent similar regulation of the oil industry, the Commission may have to set rates providing a potential return for gas exploration equal to or greater than the return anticipated from non-domestic oil exploration

Finally, it may be time for the Commission to consider the possibility of altering rate structures at the wholesale market level to discourage less desirable uses of gas. This position, advocated by Mr. 
Justice Jackson in Hope, will perhaps control the drain on existing natural gas reserves.

One other recent development deserves mention. While all other area cases have been handlcd on an adjudicatory basis, the Commission has set the Appalachian-Illinois Basin Area rate case for a rule-making proceeding. ${ }^{223}$ The reason for this approach seems twofold. First, the move suggests an attempt to expedite the process by eliminating reargument of the basic questions settled in the other rate cases. Second, and most important, the Commission is considering a departure from the cost method and has asked for comment upon the departure in the rule-making context. In an apparent attempt to simplify administration, the Commission has proposed that the rates in these two areas be based upon the cost of purchasing southwestern-produced gas at delivery points in the Appalachian-1llinois area. The Appalachian-1llinois Basin accounts for a very small percentage of national gas production; yet the industry in these areas is marked by a host of small produeers. While establishment of the price for area gas on the basis of gas prices outside the area may result in excessive returns to some produeers, this disadvantage may be offset by the ease of administration, especially since the volume of gas involved is small. The possibility of excessive returns is further reduced by the comparatively expensive gas production costs in the area. Although adoption of the basingpoint system in these and other minor production areas appears reasonable, the system should not herald the abolition of all regulation and reversion to market price in the major production areas without extensive additional consideration.

Both Commissioner O'Connor and Commissioner Bagge have recently suggested abandonment of the area cost-of-service approach. Commissioner O'Connor has advocated a generally applicable basing point pricing system similar to that proposed in the Appalachian1llinois Basin case.

It may be in the public interest to develop a pricing technique for future gas suppliers founded upon a careful evaluation of producer cost of new gas supplies at a significant base point, such as the prolific offshore area, which

223. Appalachian and Illinois Basin Areas, Rulemaking Proceeding Dkt. No. R-371 (FPC Oct. 16, 1969) (reported in FPC News, Oct. 17, 1969, at 4). See generally Shapiro, The Choice of Rulcmaking or Adjudication in the Developmont of Administrative Policy, 78 HARv. L. REV. 921 (1965). 
evaluates comparable new supplies in areas closer to interstate end markets in light of transportation economics. ${ }^{224}$

Contending that present area rates have depleted gas resources both by increasing consumer demand for the relatively inexpensive fuel and failing to provide adequate incentives for exploration for additional reserves, Commissioner Bagge cites the rise of intrastate wholesale rates to approach the level of interstate rates. Thus, he argues, intrastate demand is eating into potential interstate supply. Moreover, he contends, the importation of liquid natural gas at significantly higher prices also indicates the inadequacy of domestic supplies.

[G]as is not presently available in sufficient quantities . . . to moderate the market price of new supply sources that are moving in to satisfy unmet demand. In this situation... the role facing government policy in the seventies is not so much to nurture the competitive vigor of base suppliers . . . as it is to reinvigorate the base supply itself. Without a dynamic base supply of natural gas, the interstate market will not be able to compete for supplies with the unregulated intrastate market. Nor will there be any effective price competition for the unconventional higher-priced supplies that are knocking at the market door. But a base supply, reinvigorated, can be the key to the price levels at which these new sources enter and can place the consumers less at the mercy of the supplementary sources. ${ }^{225}$

Commissioner Bagge's solution is, in essence, a return to free market pricing "acknowledging the existence of the higher priced alternative sources and basing the domestic producers' price upon those sources with an appropriate discount for the cost of transportation." Specifically he suggests the adoption of price indices based upon the "market price of the highest or the average price of the alternate increment of gas" available at the point of sale.

The significance of this approach lies in the complete abandonment of cost and fair return on investment as the basic ingredients in pricing; rather, he suggests the allowance of inflated prices in the expectation that this will induce discovery of new supplies of gas. Although nothing assures that the increased profits will in fact bring forth the desired additional gas supply, on the basis of economic theory one can reason that it should. The irony of the proposal rests in its implicit statement that price control, assumed necessary in the past when supply was adequate, is not desirable when supply diminishes

224. O'Conner, Gas Supply and the Role of the Independent Producer, PuB. Util. Fort., Oct. 23, 1969, at 26, 33 .

225. Address by Commissioner Bagge, supra note 218. 
vis-à-vis demand. If the market structure or conduct permits monopolistic pricing, price control appears even more imperative during a period of low supply. This seems particularly true when the maximum control price reflects the higher cost of alternative sources of gas, almost guaranteeing an unreasonable return on a cost basis for the less expensive local supply.

Nevertheless, it might be desirable to pursue such a policy if this is the only way to assure an adequate supply. This suggestion may be premature since, arguably, the area rate approach has not yet had an adequate chance to deal with the problem. In theory the area rate, predicated upon a full recovery of costs and fair return on investment considering the risks involved, should be sufficient to encourage the necessary level of exploration and development. Several possibilities for its apparent failure to provide the necessary incentive for exploration and development have been suggested above: the relationship to the oil market; the possibility of concerted action by the producers to require an increase in or elimination of the area rates; and the possibility that the rate of return reflected in the area price is not sufficient to offset the risks involved relative to the potential return on other investment opportunities. While the exact source or nature of the problem is uncertain, the area approach needs flexibility to reflect the greater expense and risk involved in the type of research and exploration needed to bring forth future supplies. The Commission has responded to this need in the manner indicated above, suggesting that the area rate approach deserves a fair trial in light of adjustments following Permian.

\section{CONCLUSION}

The Supreme Court's decision in the Permian Basin Area Rate Cases is not the "final word" on the regulation of sales by natural gas producers. Historical analysis of this regulation has shown that it is not static but must adapt to new situations as they arise. In addition, economic characterization of the natural gas industry does not fit easily within the classic definitions of monopoly, monopsony, oligopoly, or even workable competition. The industry encompasses, at some point, characteristics of each of these, making "final" regulatory decision impossible.

Although adoption of the area rate approach provides evidence of the need for new regulatory methods, the precipitating factor for its adoption was not the industry's new conditions but the need for an 
administratively feasible system. The Commission, attempting to reduce its own workload, was forced to abandon outmoded approaches to the regulation of natural gas producers' prices and to adapt prior methods to existing circumstances.

Because the adoption of the area approach and its implementation resulted from judgments based upon sketchy statistics, the approach is still subject to reasonable doubt. Time is needed to test the theoretical bases supporting the decisions of the Court and the Commission. The decisions have, however, had one beneficial effect. Nine years have elapsed since the Commission adopted this approach, and over two years have passed since its "final" affirmation by the Supreme Court. During this time the administrative workload of the FPC has experienced a marked metamorphosis. While the area proceedings still require considerable effort by the Commission, they are clearly less burdensome than the former task of dealing with producers' rates on an individual basis. Computerization of the cost dat a should further lighten the administrative burden of rate regulation. Nevertheless, the administration of rates is still a burdensome and expensive task. One may question whether it is worth all the time and expenses. In general, however, the area approach has advantages beyond administrative feasibility once regulation of some sort is assumed. The ultimate consumer is assured a fair price based at least in part upon cost valuation rather than the field price technique which is less certain to achieve competitive pricing. The transmission firms have an incentive to bargain because reductions in contract prices may inure to their benefit. The efficient producer is served by higher profits, and the average producer should be able to recover an adequate return.

The area rate approach will undoubtedly undergo more revisions before a completely satisfactory method can be achieved. In a sense, however, finality will never occur, since a periodic reappraisal of the cost basis for the area rates will be required. Moreover, functional adjustments may be necessary. In dealing with the gas industry's complex economic structure and unique regulatory history, the Federal Power Commission must be aware of the constant need for response to changes within the industry, to exterior forces that alter its traditional composition, and to the industry's relation to the economic structure of the nation. 